Artigo

doi: $10.20396 /$ rho.v17i3.8650923

(1) (9)

\title{
A ÚLTIMA REFORMA DA EDUCAÇÃO SOVIÉTICA
}

\author{
Marisa Bittar ${ }^{1}$ \\ Amarilio Ferreira Junior ${ }^{2}$
}

\section{Resumo}

Este artigo tem como objetivo discutir o texto da última Reforma educacional empreendida pela União das Repúblicas Socialistas Soviéticas (URSS), que passou a vigorar em abril de 1984. Ela entrou em vigência um ano antes de o governo de Mikhail Gorbachev (1985-1991) colocar em execução a sua reforma econômica (perestroika) e política (glasnost) nos âmbitos do Estado e da sociedade soviéticas. Em termos metodológicos, optamos por uma breve sistematização inicial sobre o contexto histórico que levou à extinção da URSS. Em seguida, analisamos o próprio texto da Reforma, que é nossa principal fonte e foi publicado em espanhol no jornal semanário NM Novedades de Moscú (Suplemento). Após as conclusões, como fonte complementar, apresentamos uma seleção de fotografias que expressam o conteúdo do artigo.

Palavras-chave: Educação socialista. Reforma educacional. Trabalho e ideologia.

\section{THE LAST EDUCATIONAL REFORM OF THE SOVIET UNION}

\begin{abstract}
This article aims to present the text of the last educational reform undertaken by the Union of Soviet Socialist Republics (USSR), which came into force in April 1984. This reform came into effect one year before Mikhail Gorbachev's (1985-1991) to implement its economic (perestroika) and political (glasnost) reforms in the realms of the state and of Soviet society. We have chosen to presenta brief systematization of both the historical context that led to the extinction of the USSR and the document concerning that reform. The text of the educational reform we use was published in the Spanish version of the weekly newspaper NM Novedades de Moscú (Suplemento). Finally, we selected some photos on the subjects discussed in the article.
\end{abstract}

Keywords: Socialist education. Educational reform. Work and ideology. 
Artigo

doi: $10.20396 /$ rho.v17i3.8650923

\section{INTRODUÇÃO}

O objetivo deste artigo é apresentar ao público brasileiro, particularmente para os pesquisadores em educação brasileira, a última Reforma educacional promovida pela União das Repúblicas Socialistas Soviéticas (URSS) ${ }^{3}$. Ela foi aprovada pelo Comitê Central (CC) do Partido Comunista da URSS (PCUS) no dia 10 de abril de 1984 e promulgada pelo Soviete Supremo da URSS ${ }^{4}$ em 12 de abril do mesmo ano, fato que ocorreu antes da ascensão de Mikhail Sergueyevitch Gorbachev ${ }^{5}$ à secretária geral do PCUS, que ocorreria em março de 1985. Depois, com a elevação do próprio Gorbachev à presidência da URSS, em março de 1990, o curso das reformas econômicas e políticas introduzidas pelo seu governo assumiu um acelerado processo de radicalização, notadamente nas laborações referentes à reorganização da planificada economia soviética ${ }^{6}$. No período transcorrido entre março de 1985 e dezembro de 1991, durante o qual o governo soviético colocou em execução a perestroika (reestruturação econômica) e a glasnost (transparência política), como programas que objetivavam democratizar o socialismo real ${ }^{7}$, a União Soviética foi perpassada por turbulências de toda ordem que acabaram por colocar fim à experiência histórica iniciada em outubro de 1917 quando os bolcheviques assumiram o poder no exImpério czarista.

Considerando este grave contexto histórico, partimos do pressuposto de que, embora a mencionada Reforma educacional tenha sido implementada pelo governo soviético a partir de 1984, os seus efeitos pedagógicos se perderam na voragem combinada de acontecimentos econômicos e políticos que levaram à derrocada da União Soviética em dezembro de 1991. Essa Reforma aprovada pelo Soviete Supremo continha os seguintes itens: I. A escola no contexto do aperfeiçoamento do socialismo desenvolvido; II. Estrutura do ensino geral médio e profissional; III. A qualidade do processo de ensino e da educação; IV. Instrução laboral, educação e orientação profissional; V. Educação social e familiar das crianças e adolescentes; VI. O professor na sociedade soviética; VII. A base material do ensino; VIII. A gestão da instrução pública. (UNIÓN SOVIÉTICA, 1984, p. 4 Et seq.).

O documento da Reforma foi publicado no jornal NM Novedades de Moscú (Suplemento), em abril de 1984 sob o título de "Orientaciones fundamentales de la reforma de la enseñanza general y profesional”. No período do governo de Gorbachev, esse semanário, cuja coleção completa pode ser encontrada na Biblioteca do Congresso dos Estados Unidos (Library of Congress -https://www.loc.gov/) desempenhou importante papel em defesa da perestroika e teve o seu protagonismo político-ideológico analisado pela historiadora espanhola Magdalena Garrido Caballero, da Universidad de Murcia, da seguinte forma:

Novedades de Moscú (NM) se presentaba en 1990 como "un periódico popular independiente". La plataforma formada por E. Yakovlev ${ }^{\mathbf{8}}$, su director, y los copresidentes: Alexandr Guelman, Yuri Rikhov, Alexandr Tsipko, el encargo de la sección española era Anatoli Efremov, se proclamaban como el periódico de la abertura democrática, que había aglutinado experiencia durante los años de la Perestroika, y lejos de ser disuelto, se propugnaba como un semanario renovado, cuyo leitmotiv era la libertad de prensa, la verdad histórica "por amarga que esta fuese", el diálogo constructivo, la conciliación nacional, eliminar el lenguaje de enemistad clasista y apostar por un "Estado libre, próspero y civilizado". El seminario cristalizó el espíritu de transparencia informativa, la glasnost, fruto de 
Artigo

doi: $10.20396 /$ rho.v17i3.8650923

los tiempos nuevos, en los que los periódicos cambiaban de dirección y no siempre quedaba claro si se trataba de un hecho legal arbitrario. La tirada de Novedades de Moscú era de dos millones de ejemplares. (CABALLERO, 2011, p. 45-46).

O exemplar que aqui utilizamos compõe o nosso acervo pessoal sobre História da Educação e sobre a Revolução de 1917. Tivemos o privilégio de viver e estudar na União Soviética na época em que esses fatos aconteceram e pudemos acompanhar de perto o processo que estava em curso, sem, contudo, prevermos o seu desfecho. Desde então, mantivemos este e outros documentos relativos à Revolução Russa, ao mesmo tempo em que procuramos compreender a complexidade dessa experiência histórica, exercício intelectual árduo seja pela sua essência política seja pela profunda relação que com ela tivemos. Em diferentes momentos do passado planejamos publicar o documento dessa Reforma e analisá-la, mas acabávamos nos decidindo pelo seu adiamento e pela maturação dos acontecimentos ao longo do tempo, já que este é o senhor da História. Decidimos, por fim, que a publicação deste nosso estudo coincidisse com os cem anos comemorativos à Revolução Russa de 1917. Assim fazendo, prestamos o nosso reconhecimento ao povo soviético e gratidão por termos estudado, tal como tantos outros estrangeiros, no seu sistema de educação pública. Sem essa vivência, não nos teria sido possível interpretar a educação socialista.

\section{OS ÚLTIMOS TEMPOS DA UNIÃO SOVIÉTICA (1985-1991)}

Com o título acima, não objetivamos fazer uma análise sistemática de todos os aspectos relativos aos quase sete anos do governo de Mikhail Gorbachev, o último da União Soviética, mas, sim, indicar elementos que possam contribuir para a compreensão do contexto histórico no qual transcorreu a Reforma educacional de 1984. Apresentaremos, portanto, uma breve panorâmica dos acontecimentos econômicos e políticos que, isolados ou combinados, levaram à extinção da URSS setenta e quatro anos depois da Revolução de 1917. Para isso, empregamos a literatura ${ }^{9}$ já existente em língua portuguesa sobre este que é considerado um dos fatos mais dramáticos do século XX: o fim do Estado socialista que começou a ser erigido pelos bolcheviques nos marcos da Primeira Guerra Mundial (19141918).

Em decorrência da velocidade com que os acontecimentos econômicos e políticos transcorreram, da escassa informação sistematizada sobre eles e das imbricações contraditórias que engendraram, resolvemos elaborar um quadro concernente ao período Gorbachev como uma espécie de roteiro que possibilite visualizar o conjunto dos episódios ocorridos entre março de 1985 e dezembro de 1991. Ele tem caráter seletivo do ponto de vista dos fatos que foram arrolados, ou seja, priorizamos exclusivamente aqueles referentes às esferas econômicas e políticas que estão relacionados, segundo o nosso entendimento, diretamente com o fim da União Soviética.

Quadro 1 - Governo de Mikhail Gorbachev (1985-1991)

\begin{tabular}{|c|c|}
\hline \multicolumn{2}{|c|}{ GOVERNO DE MIKHAIL GORBACHEV (1985-1991) } \\
\hline ANO & ACONTECIMENTOS \\
\hline 1985 & 11 de março: Gorbachev foi eleito secretário-geral do PCUS; \\
\hline
\end{tabular}

Rev. HISTEDBR On-line, Campinas, v.17, n.3 [73], p.732-765, jul./set. 2017 
Quadro 1 - Governo de Mikhail Gorbachev (1985-1991)

(continuação)

\begin{tabular}{|c|c|}
\hline & $\begin{array}{l}\text { de outubro: Gorbachev apresentou seu plano de reestruturação econômica (perestroika) } \\
\text { ezembro: Boris Yeltsin foi nomeado primeiro-secretário do PCUS. }\end{array}$ \\
\hline 1986 & $\begin{array}{l}06 \text { de março: O } 27^{\circ} \text { Congresso do PCUS reorganizou suas instâncias dirigentes; } \\
26 \text { de abril: Uma unidade de força da usina atômica de Chernobyl (Ucrânia) explodiu, causando } \\
\text { o pior desastre nuclear do pós Segunda Guerra Mundial; } \\
23 \text { de dezembro: O físico dissidente Andrei Sakharov foi libertado de sua prisão domiciliar na } \\
\text { cidade de Gorki (hoje, seu nome voltou a ser Níjni Novgorod). }\end{array}$ \\
\hline 1987 & $\begin{array}{l}\text { Novembro: O secretário do PCUS em Moscou, Boris Yeltsin, criticou publicamente a lentidão } \\
\text { das reformas econômicas e políticas (glasnost). Em seguida, foi afastado dos cargos que ocupava } \\
\text { na estrutura partidária; } \\
08 \text { de dezembro: Assinou em Washington, durante reunião de cúpula com o presidente Ronald } \\
\text { Reagan, o tratado de eliminação de mísseis de médio alcance que estavam instalados na Europa. }\end{array}$ \\
\hline 1988 & $\begin{array}{l}\text { Inho/julho: } 19^{\text {a }} \text { Conferência do PCUS, que enfatizou a necessidade da criação do Estado } \\
\text { emocrático de Direito na URSS; } \\
\text { gosto: As tropas soviéticas começam a se retirar do Afeganistão. A retirada seria concluída em } \\
\text { vereiro de } 1989 \text {. }\end{array}$ \\
\hline 1989 & $\begin{array}{l}5 \text { de março: } 20 \% \text { dos dirigentes do partido são rejeitados nas } 15 \text { Repúblicas nas eleições para o } \\
\text { ovo Congresso de Deputados do Povo. Boris Yeltsin foi eleito deputado com } 90 \% \text { dos votos } \\
\text { m Moscou; } \\
\text { Iaio: A URSS e a China reataram relações diplomáticas. Gorbachev emitiu sinais de apoio ao } \\
\text { ovimento estudantil chinês que defendia as liberdades democráticas; } \\
\text { ovembro/dezembro: Com a anuência da URSS, os regimes socialistas do leste europeu foram } \\
\text { esfeitos tendo sido emblemática a queda do muro que dividia a cidade de Berlim. }\end{array}$ \\
\hline 1990 & $\begin{array}{l}11 \text { de março: A República da Lituânia declara independência da URSS; } \\
14 \text { de março: Gorbachev foi eleito presidente da URSS e anunciou a "radicalização" das reformas } \\
\text { (perestroika + glasnost); } \\
\text { 01 de maio: Sob vaias, Gorbachev abandonou a Praça Vermelha durante as comemorações do } \\
\text { Dia do Trabalho; } \\
\text { Junho: No } 28^{\circ} \text { Congresso do PCUS Gorbachev isolou os denominados "extremistas" do partido. } \\
\text { Boris Yeltsin e os chamados "ultra-reformistas" abandonaram o PCUS; } \\
\text { Setembro: A URSS assinou acordo que permitiu a reunificação da Alemanha; } \\
15 \text { de Outubro: Gorbachev foi indicado para receber o Prêmio Nobel da Paz; } \\
\text { Novembro: Na Conferência para Segurança e Cooperação na Europa, Gorbachev propôs a } \\
\text { formação da "Casa Comum Europeia"; } \\
20 \text { de dezembro: O Chanceler das Relações Exteriores da URSS Eduard Shevardnadze } \\
\text { denunciou "o avanço da ditadura" e renunciou ao cargo. }\end{array}$ \\
\hline 1991 & $\begin{array}{l}\text { 07 de janeiro: Intervenção do Exército da URSS nos países do Báltico (Lituânia, Estônia e } \\
\text { Letônia); } \\
\text { Maio: Boris Yeltsin foi eleito presidente da Rússia em eleições diretas; } \\
30 \text { de julho: Gorbachev assinou com o presidente dos EUA, George Bush, o acordo Start, que } \\
\text { reduziu em } 30 \% \text { as ogivas nucleares estratégicas (mísseis de longo alcance); } \\
19 \text { de agosto: Um golpe de Estado liderado pelos setores "ortodoxos" do PCUS depôs } \\
\text { Gorbachev; } \\
21 \text { de agosto: Gorbachev voltou aos poder graças à resistência comandada por Boris Yeltsin; } \\
24 \text { de agosto: Gorbachev deu início ao processo de autodissolução do PCUS; } \\
29 \text { de agosto: O Parlamento do Povo retira de Gorbachev seus poderes especiais em assuntos de } \\
\text { economia; } \\
06 \text { de setembro: A URSS reconheceu a independência das três Repúblicas Bálticas (Lituânia, } \\
\text { Estônia e Letônia); } \\
\text { 01 de dezembro: Mais de } 80 \% \text { dos ucranianos votam pela independência do País em relação à } \\
\text { URSS; }\end{array}$ \\
\hline
\end{tabular}


Artigo

doi: $10.20396 /$ rho.v17i3.8650923

Quadro 1 - Governo de Mikhail Gorbachev (1985-1991)

(conclusão)

08 de dezembro: Rússia, Ucrânia e Bielo-Rússia decidem formar uma Comunidade de Estados Independentes (CEI);

21 de dezembro: Mais oito Repúblicas Soviéticas aderem à CEI, que declaram extinto o cargo de presidente da URSS.

Fonte: Quadro elaborado pelos autores.

Tal como podemos observar, a dinâmica dos acontecimentos econômicos e políticos assumiu uma velocidade muito acelerada e totalmente incomum no período decorrido de 1985 a 1991. Se partirmos do pressuposto de que esses episódios, isolados ou combinados, constituíram-se no leitmotiv responsável pela desintegração da União Soviética, podemos considerar a existência de um determinado paradoxo histórico: a corrida armamentista contra a outra superpotência nuclear - os EUA - não foi fator de garantia para a existência da própria União Soviética. Isso porque, desde o fim da guerra civil (1921) vigorou a política segundo a qual os altíssimos gastos com o arsenal armamentista eram necessários a fim de garantir a existência do Estado socialista contra as investidas dos países capitalistas. No entanto, apesar desse poderio, o socialismo real se desestruturou por dentro, fruto da associação orgânica existente entre a burocracia estatal e a repressão contra todos os opositores das políticas emanadas do Partido Comunista da União Soviética. Estudos que temos empreendido sobre a Revolução de 1917 e seus desdobramentos ${ }^{\mathbf{1 0}}$, além da experiência pessoal vivida nos anos de 1980, nos permitem concluir que o fim dessa experiência histórica está diretamente ligado a três características que marcaram o processo de constituição do Estado soviético: militarismo, burocratismo e autocratismo. Analisando o fim da URSS, o marxista brasileiro José Paulo Netto, em artigo publicado em 1994, prognosticou o seguinte:

[...] a crise do Socialismo Real tem uma inequívoca centralidade política, a que remetem os bloqueios do desenvolvimento econômico: deriva da ausência de uma plena socialização do poder político - só a implementação da democracia socialista, capaz de socializar efetivamente o poder político e rebater imediatamente no ordenamento econômico, com reais processos autogestionários aptos para otimizar (com a liquidação de traços e excrescências burocráticas) e alocação central de recursos, poderia garantir o desenvolvimento exitoso das experiências pós-revolucionárias. (NETTO, 1994, p. 66).

Se assim o foi, podemos considerar que a dissincronia manifesta entre economia (planificada) e política (ausência de democracia) foi a combustão que propiciou, ao longo de quase sete décadas, a deflagração da crise sistêmica que levou ao fim uma experiência revolucionária que, internacionalmente, inspirou lutas, movimentos e conquistas. Portanto, essa desintegração a partir de 1985, acontecimento inesperado no contexto internacional, como analisou Mario Alighiero Manacorda ${ }^{\mathbf{1 1}}$, tinha profundas raízes. Essas condicionantes foram agravadas com a fatura que o socialismo real teve que tributar, no contexto da Guerra Fria (1947-1991), ao processo desenfreado da corrida armamentista nuclear, particularmente a partir da década de 1970 quando começou a se configurar a revolução técnico-científica (microeletrônica, microbiologia e energia nuclear) ${ }^{\mathbf{1 2}}$. Em outras palavras: a lógica da Guerra Fria, com sua polaridade ideológica que dividiu o mundo, impôs uma disputa que foi 
Artigo

doi: $10.20396 /$ rho.v17i3.8650923

beneficiária de recursos financeiros aplicados em armamentos, recursos estes que poderiam ter como destino as políticas públicas de caráter social.

Portanto, o plano econômico apresentado por Gorbachev em outubro de 1985, visava reestruturar uma economia que não era baseada na propriedade privada dos meios de produção (terra, indústria, comércio e sistema monetário) e que vinha sendo planificada desde o final da década de 1920 por meio dos Planos Quinquenais. Tratava-se de uma economia assentada em relações sociais de produção marcadas pela ausência das relações complexas e contraditórias que o mercado estabelece entre produtores e consumidores de bens materiais e simbólicos. Em outras palavras: os processos produtivos que garantiam a existência material e espiritual ${ }^{\mathbf{1 3}}$ da sociedade soviética não eram impactados diretamente, por exemplo, pelas consequências da aplicação massiva de ciência e de tecnologia no âmbito das forças produtivas (trabalho, máquinas ferramentas e matérias primas). Havia sido necessário empregar a forma de produção extensiva desde o início da Revolução a fim de garantir emprego e alimentos para todos. Todavia, de acordo com a perestroika, nessa nova etapa do socialismo seria preciso empregar métodos intensivos de produção, ou seja, compatíveis com os desafios da automação.

A sociedade soviética, do ponto de vista de bens materiais, vivia com pouco. A sua economia, que para ser socializada, caracterizou-se desde o início pela escassez de produtos, gerava grande impacto em quem, como nós, tinha a experiência de vida originada em valores típicos das sociedades capitalistas. Ao contrário da abundância de bens, da propaganda massiva que estimula incessantemente o consumo supérfluo e os desperdícios, a sociedade soviética vivia à base do consumo das suas necessidades essenciais. Vestuário, mobiliário e eletrodomésticos eram poucos. Não existia moda nem propaganda. Os cálculos nas unidades produtivas ou comerciais eram feitos com o ábaco. Esse traço do funcionamento das unidades produtivas, se por um lado demonstrava a preservação de uma tradição, por outro, indicava que a economia soviética carecia do revolucionamento das forças produtivas com base no emprego sistemático de ciência e de tecnologia, que acabava, por sua vez, gerando efeitos negativos para se determinar, em última instância, os preços das mercadorias (quantidade e qualidade) que o próprio sistema produtivo planejado colocava em circulação ${ }^{\mathbf{1 4}}$. Os impactos restringentes sobre a sociedade soviética, gerados pela burocratização do planejamento econômico, foram assinalados por Gorbachev, na obra Perestroika, da seguinte forma:

\footnotetext{
A queda das taxas de crescimento e a estagnação econômica acabaram por influenciar outros aspectos da sociedade soviética. A esfera social foi seriamente afetada por tendências negativas, o que levou ao aparecimento do chamado princípio residual, de acordo com o qual os programas sociais e culturais recebiam o que sobrava do orçamento depois da alocação de recursos para a produção. Parecia que éramos insensíveis aos programas sociais. A esfera social começou a ser relegada a posições inferiores em relação a outras em termos de desenvolvimento tecnológico, know-how, pessoal e, principalmente, qualidade do trabalho. (GORBACHEV, 1988, p. 19).
}

Assim, segundo o establishment soviético liderado por Gorbachev, a perestroika e a glasnost eram políticas imperativas para recuperar a economia da tendência de estagnação que se arrastava desde a década de 1970. Pois, a imbricação política entre o PCUS e as 
instituições estatais encarregadas da planificação da economia, desde o final dos anos 1920, havia gerado burocratismo e autoritarismo no processo de edificação do socialismo real. Documentos partidários registram as estratégias empregadas para elevar operários leais ao Partido aos postos de comando da economia estatal, processo que foi acelerado no ano da morte de Lênin (1924) para aumentar a participação da classe operária em detrimento da camponesa, que era a ampla maioria, mas cuja influência, segundo esses documentos, precisava ser detida, assim como a de outras camadas refratárias à coletivização e socialização da economia. Para tal objetivo, durante alguns anos, ficou proibido o ingresso de camponeses no Partido enquanto se aumentava o de operários. Tudo isso no auge da disputa entre os principais grupos dentro do Partido e de suas visões distintas sobre a construção do socialismo, principalmente entre trotskistas e leninistas, caracterizando um traumático processo de expurgos que levou à exclusão dos primeiros. Essa estratégia de construção do socialismo evidencia a forma pela qual a revolução bolchevique transformou uma classe que era minoritária, quase inexistente, em classe dominante. De acordo com esses documentos, não havia experiência em lugar algum do mundo que a Revolução pudesse copiar, por isso ela teve de criar os seus próprios mecanismos.

Os resultados desse duro processo atingiram o objetivo de socializar a economia, mas, depois de sete décadas, segundo Gorbatchev, era preciso reavaliá-lo a fim de dar prosseguimento ao socialismo. Para ele, as consequências advindas dessa longa trajetória repercutiram nos âmbitos superestruturais engendrando traços negativos em todos os aspectos da vida cotidiana da população, produzindo uma ideologia oficial de enaltecimento dos feitos positivos do socialismo real e reprimindo politicamente as manifestações críticas sobre as mazelas produzidas pelo binômio "autocracia e burocracia". No aspecto econômico propriamente dito, era nítida a estagnação. Quanto ao político, a proibição sistemática da crítica acabou gerando autocensura generalizada entre a população. Nesse sentido, considerou Gorbachev:

A propaganda do sucesso, real ou imaginário, estava ganhando terreno. Os elogios e o servilismo foram encorajados; as necessidades e opiniões dos trabalhadores comuns, geralmente ignoradas. Nas ciências sociais, a teoria escolástica foi estimulada e desenvolvida; o pensamento criativo, expulso, declarando-se juízos voluntaristas e supérfluos como verdades incontestáveis. As discussões científicas e teóricas, indispensáveis ao desenvolvimento do pensamento e ao esforço criativo, foram emasculadas. Tendências negativas semelhantes também influenciaram a cultura, as artes e o jornalismo, bem como os métodos de ensino e a medicina, onde a mediocridade, o formalismo e o panegírico retumbante vieram à tona. (GORBACHEV, 1988, p. 21).

Para combater tais tendências ideológicas negativas que levavam a sociedade soviética à paralisia e à estagnação, as reformas visavam promover "[...] uma abertura democrática[...]" que possibilitasse a "[...] interdependência entre o aparelho partidário e o aparelho de Estado [...] a fim de assegurar a reconstrução da economia". (POMERANZ, 1990, p. 14). Ou seja: visavam romper com o imobilismo econômico e político gerados, historicamente, pelo que poderíamos denominar de "Partido-Estado" que governava o país. Assim, a perestroika fundamentava-se em uma nova estratégia econômica baseada nos seguintes princípios: 
I. A reorientação social do desenvolvimento econômico, isto é, reorientação de todos os ramos da economia em direção ao homem, à mais plena satisfação de todas as suas necessidades;

II. A política de incremento da eficiência e da qualidade na base da aceleração do progresso técnico-científico, que visava à modificação radical da estrutura, dos fatores e das fontes de crescimento econômico;

III. A reforma econômica do sistema de gestão, considerada a mais importante, dela depende todo o resto. (AGANBEGUIAN, 1990, p. 50 Et seq.).

Portanto, a perestroika associada à glasnost tinha como objetivo o aprimoramento do socialismo real por meio da democratização da sociedade soviética - separação, por exemplo, entre o Partido e o Estado - e alçar a economia planejada a um novo patamar de produtividade que atendesse de forma plena "as necessidades e as satisfações" de consumo da população soviética. Contudo, as características do processo histórico impediram que tal objetivo fosse alcançado e quando as reformas políticas e econômicas tiveram início, na segunda metade da década de 1980, a sociedade soviética não foi capaz de reverter o declínio do socialismo real que se arrastava desde a década anterior. A esse respeito, o historiador Eric Hobsbawm, na obra Era dos extremos, foi categórico ao assinalar que:

“[...] à medida que a década de 1970 passava para a de 1980, foi ficando cada vez mais claro que havia alguma coisa de seriamente errado em todos os sistemas socialistas que assim se consideravam. A diminuição no ritmo da economia soviética era palpável: a taxa de crescimento de quase tudo que nele constava, e podia ser contado, caiu constantemente de um período de cinco anos para outro após 1970: produto interno bruto, produção industrial, produção agrícola, investimento de capital, produtividade de trabalho, renda real per capital. (...) $\mathrm{Na}$ verdade, na década de 1970 era claro que não só o crescimento econômico estava ficando para trás, mas mesmo os indicadores sociais básicos, como o da mortalidade, estavam deixando de melhorar. Isso minou a confiança no socialismo talvez mais que qualquer outra coisa, pois sua capacidade de melhorar a vida da gente comum através de maior justiça social não dependia basicamente de sua capacidade de gerar maior riqueza. (...) Por outro lado, o termo nomenklatura, praticamente desconhecido antes de 1980, a não ser como parte do jargão administrativo do PCUS, passou a sugerir precisamente a fraqueza da interessada burocracia do partido da era Brejnev: uma combinação de incompetência e corrupção. E, na verdade, tornou-se cada vez mais evidente que a própria URSS operava basicamente por um sistema de patronato, nepotismo e suborno". (1995, p. 456 , Et Seq.).

Assim sendo, as reformas que visavam reforçar a União Soviética; democratizar o socialismo; superar a bipolaridade ideológica entre os sistemas capitalista e socialista; estabelecer uma nova ordem mundial baseada na coabitação pacifica; e reduzir as distâncias entre países pobres e ricos - fracassaram menos de sete anos depois da ascensão de Mikhail Gorbachev à Secretária-geral do PCUS. Por meio da TV estatal, em dezembro de 1991, ele fez um pronunciamento que pode ser considerado como a despedida da União Soviética quase setenta anos depois da sua fundação. Nesse discurso ele abordou os principais motivos que considerava responsáveis pelo dramático momento histórico que o mundo assistia com o colapso do país dos sovietes:

Sendo a minha última oportunidade para me dirigir a vocês como presidente da URSS, eu acho necessário informar o que acho do caminho percorrido desde 1985. 


\begin{abstract}
Eu acho isso importante porque houve muitos julgamentos controversos, superficiais e parciais feitos a respeito. $\mathrm{O}$ destino quis que quando eu me encontrei na direção deste Estado, já era claro que algo estava errado neste país. Nós tínhamos muito de tudo - terra, petróleo e gás, outros recursos naturais - e havia intelecto e talento em abundância. Entretanto, nós vivíamos muito pior do que as pessoas nos países industrializados viviam. E nós cada vez mais ficávamos atrás deles. O motivo era óbvio mesmo então. O país se sufocava nos grilhões de um sistema burocrático. A sociedade estava condenada a servir à ideologia e a carregar o pesado fardo da militarização excessiva. Ela havia chegado ao limite do suportável. Todas as reformas tíbias - e houve muitas delas - fracassaram uma após a outra. Este país não ia a lugar nenhum e nós não podíamos viver da maneira como vivíamos. Nos tínhamos que mudar tudo radicalmente. (...) O processo de renovar este país e trazer uma mudança dramática na comunidade internacional provou ser muito mais complicado do que qualquer um poderia imaginar. Entretanto, vamos dar crédito devido ao que foi feito até agora. Esta sociedade adquiriu liberdade. Ela foi libertada politicamente e espiritualmente, e esta é a mais importante conquista que nós tivemos que enfrentar. E nós ainda não a conseguimos, porque nós ainda não aprendemos a usar a liberdade. (GORBACHEV, 1991, p. 3).
\end{abstract}

Terminava, assim, a experiência societária iniciada pelos bolcheviques em 1917. Esse desfecho colocou em xeque a convicção ideológica de que era possível construir a sociedade socialista com base na concepção soviética, isto é, uma economia planificada comandada por um Estado centralizador que eliminou as relações sociais que são inerentes ao processo de produção, circulação e consumo das riquezas (materiais e espirituais) produzidas pelo trabalho humano. Quanto ao aspecto político propriamente dito, a dissolução da União Soviética gerou duro impacto no pressuposto ideológico de que aquele projeto societário era a única forma historicamente possível de manifestação do socialismo. Como consequência, esse fato, que na interpretação de Eric Hobsbawm, acelerou o encerramento do século $\mathrm{XX}$, provocou grave crise nas esquerdas mundiais e também no marxismo, que era identificado internacionalmente como a teoria que embasava aquele sistema.

Ao mesmo tempo, o mundo capitalista, baseado nos pressupostos neoliberais, enfrentou sucessivas crises desde o último decênio do século XX, como foi o colapso global produzido pelo capital financeiro especulativo em 2008-2009. Assim, ao contrário dos ideólogos que profetizaram o "fim da História", com o suposto triunfo definitivo do capitalismo e a derrota do socialismo, as crises cíclicas do sistema capitalista mundial têm oferecido perspectivas históricas fecundas para que as esquerdas mundiais repensem continuamente a utopia socialista. Compreender a experiência que nos legou a Revolução Russa é fundamental se pretendemos manter um horizonte de vida além da sociedade de consumo e do individualismo. Uma Revolução que foi capaz de socializar a economia, implementar políticas públicas eficientes, como a edificação de um sistema de educação popular para todos e o acesso aos bens culturais. Muito herdamos dos "dez dias que abalaram o mundo" e talvez o aprendizado mais profundo dessa experiência histórica seja o de que a socialização da economia deve ser feita juntamente com a socialização da política.

\title{
UMA ESCOLA PARA O SOCIALISMO DESENVOLVIDO
}


Nesta parte, analisaremos a Reforma de 1984 utilizando como fonte o seu próprio texto. Inicialmente, realizamos uma breve incursão às primeiras ações de educação adotadas pela Revolução a fim de darmos visibilidade aos desafios que foram enfrentados até chegar à Reforma de 1984. De fato, a rapidez e eficiência da política de alfabetização do Estado bolchevique ficaram registradas como uma prática inédita e bem-sucedida; pois, até então, o mundo não dispunha de uma experiência que pudesse superar em tão curto espaço de tempo índices de analfabetismo como aqueles, isto é, herdados de uma sociedade que, até 1861, fora baseada na servidão feudal dos camponeses e carregava um longo passado de exclusão educacional.

O papel de Lênin foi determinante na política de educação do Estado soviético. Foi graças ao seu prestígio que, em 1919, uma Resolução do Partido Comunista determinou "[...] instrução geral e politécnica, gratuita e obrigatória para todas as crianças e adolescentes dos dois sexos, até os 17 anos". (MANACORDA, 1989, p. 314-315). Para edificar um sistema assim, no entanto, era necessária uma tarefa precedente, já que o regime czarista havia deixado escassez de escolas e analfabetismo quase pleno. Para termos uma ideia mais próxima dessa situação, em 1913 a Rússia tinha cento e sessenta milhões de habitantes, dos quais apenas cento e sessenta mil crianças estavam na escola.

Nesse grave panorama, a alfabetização contou com a férrea defesa do líder da Revolução. Em 1920, convencido de que ela fracassaria se a Rússia Soviética não fosse modernizada e de que, para isso, eram urgentes a eletrificação e a alfabetização, Lênin exortou a Juventude Comunista a ser alfabetizadora. Nenhuma ação política, naquele momento, segundo ele, era mais revolucionária. Com palavras de ordem apenas o socialismo não seria construído, era preciso estudar as ciências, trocar as trincheiras de ontem pelas carteiras escolares e, concomitante à alfabetização, teriam de eletrificar o país. As duas eram missões gigantescas, uma no plano superestrutural (educação) outra no plano material (eletrificação).

Pouco anos depois, ao tomar conhecimento de dados contidos no documento "O grau de alfabetização na Rússia", Lênin, já doente, ditou o texto "Páginas do Diário ${ }^{15}$ advertindo para o fato de que, enquanto "tagarelavam sobre cultura proletária", dados empíricos mostravam que, em 1920, de cada mil habitantes (homens e mulheres) na Rússia Soviética, apenas 319 sabiam ler e escrever. Em 1897, eram 223. (LÊNIN, 1980b, p. 653). Sendo assim, ainda se fazia muito pouco, pouquíssimo, para deslocar o orçamento de Estado para a satisfação, em primeiro lugar, das necessidades da instrução pública elementar. Os números mostravam, portanto, que era necessário trabalho duro e persistente para superar o atraso herdado da época czarista e alcançar "[...] o nível de um Estado civilizado comum da Europa Ocidental". (LÊNIN, 1980b, p. 653). Contra a burocracia, desferiu dura crítica ao excesso de pessoal em "[...] qualquer editora do Estado, fora de quaisquer preocupações de que a atenção principal do Estado deve ser não pelas editoras, mas para que haja leitores, para que haja um maior número de pessoas que saibam ler [...]".Pois, “[...] por um antigo (e mau) costume, ainda dedicamos muito mais tempo e energias às questões técnicas, por exemplo, à questão das editoras, do que à questão política geral do grau de alfabetização do povo". (LÊNIN, 1980b, p. 654). Esse artigo exerceu influência direta sobre as tarefas da instrução. O Comissariado do Povo da Instrução Pública (órgão máximo da educação soviética) divulgou-o amplamente determinando a todos os departamentos de instrução da Rússia 
medidas concretas para superar a situação. A campanha foi realizada sob dificuldades extremas: fome, frio, escuridão. Em 1920, quando a Comissão Extraordinária para o Combate ao Analfabetismo foi criada, só se dispunha, em média, de um lápis e um caderno para cada vinte alunos. Além disso, houve resistência contra a própria alfabetização em si, já que muitas vezes ela não era entendida como necessidade ou como um valor. A cultura camponesa, por exemplo, conflitava com a determinação do Partido em alfabetizar todos, sem exceção ${ }^{16}$.

Apesar de todos os obstáculos, e considerando ainda que o período transcorreu concomitante à política de industrialização intensiva e coletivização da agricultura (traumática e acelerada a partir de 1928), é surpreendente que às vésperas da Segunda Guerra Mundial (1939), a União Soviética já contasse com 90\% da população alfabetizada, etapa concluída até o fim da década de 1940. A eletrificação também estava realizada.

Cem anos nos separam dessa epopeia que ficou ligada ao nome do líder bolchevique de 1917. Por isso, no texto da Reforma de 1984 consta que nas origens do sistema soviético de instrução pública estava "o grande Lênin". Durante esse período, a União Soviética passou do analfabetismo em massa à instrução secundária geral da juventude e à criação de um eficiente e diversificado sistema de instrução técnico-profissional. Além disso, ocorreu amplo desenvolvimento da instrução superior e média especializada "e se aproximaram bastante os níveis de instrução entre classes e grupos sociais, entre nacionalidades e povos, homens e mulheres". Em síntese, foi criada "pela primeira vez na história universal uma escola verdadeiramente popular", que assegurou o direito de igualdade de todos para obter instrução e se converteu em principal instituição "formadora de trabalhadores qualificados". (UNIÓN SOVIÉTICA, 1984, p. 4).

Depois de sete décadas da construção desse sistema, contudo, era urgente reformar a escola, melhorar "o desempenho da instrução da juventude, de sua formação política, profissional e moral". Além de "fenômenos negativos, deficiências e negligências" que precisavam ser superadas, o Partido Comunista da União Soviética (PCUS) via no crescimento da firmeza ideológica, na instrução e preparação profissional das novas gerações "uma importante premissa para o fortalecimento da democracia socialista". (UNIÓN SOVIÉTICA, 1984, p. 4).

Com o título de "Orientações fundamentais da reforma do ensino geral e profissional", ela foi elaborada de acordo com os pontos programáticos do PCUS em junho de 1983, aprovada pela sua instância máxima (Pleno do Comitê Central) no dia 10 de abril de 1984 e, dois dias depois pelo Soviete Supremo da União Soviética. A tramitação de apenas dois dias entre uma e outra instância (Partido e Estado) é demonstrativa da superposição da primeira sobre a segunda. Ou seja, na prática, não havia separação entre Partido e Estado. O Partido governava a União Soviética e foi ele o autor da Reforma, prevista para ser integralmente colocada em prática de 1984 a 1990.0 texto é conciso, claro, e constituído pelos seguintes itens: I. A escola no contexto do aperfeiçoamento do socialismo desenvolvido; II. Estrutura do ensino médio e profissional; III. Necessidade de elevar a qualidade do ensino e da educação; IV. Instrução para o trabalho, educação e orientação profissional; V. Educação social e familiar das crianças e adolescentes; VI. O professor na sociedade soviética; VII. Reforçar a base material do ensino; VIII. Aperfeiçoar a gestão da instrução pública. (UNIÓN SOVIÉTICA, 1984, p. 4, Et seq.). 
Artigo

doi: $10.20396 /$ rho.v17i3.8650923

Como preâmbulo, o documento apresenta brevemente as características da escola soviética, "[...] um dos maiores orgulhos da Revolução". Esse feito é considerado "parte inerente da história da sociedade soviética e das heroicas realizações revolucionárias" de seu povo, "um tesouro para a experiência universal da humanidade". Com a convicção nas "vantagens históricas do socialismo frente ao capitalismo", o objetivo da Reforma foi indicar os novos desafios da escola soviética a fim de compatibilizá-la com a etapa do "socialismo desenvolvido" (UNIÓN SOVIÉTICA, 1984, p. 4), denominação empregada para distinguir a fase iniciada a partir de 1960 das décadas precedentes.

Segundo o texto, "a etapa contemporânea de desenvolvimento vertiginoso e harmonioso da economia e da cultura, do aperfeiçoamento das relações sociais e da superestrutura socialista, do homem como principal força produtiva", requeria um enfoque novo e mais amplo da instrução e formação de novas gerações. Era preciso, pois, uma educação compatível com o avanço tecnológico pelo qual passava o mundo capitalista e frente ao qual a União Soviética estava atrasada, já que a estrutura da "[...] instrução, da educação e da orientação profissional" não correspondia aos requisitos da revolução técnicocientífica e das "necessidades da economia nacional". (UNIÓN SOVIÉTICA, 1984, p. 4). Assim, a sociedade do conhecimento ("Znanie") exigia a automatização da produção, o crescimento da produtividade do trabalho e uma nova escola.

Se nas primeiras décadas da Revolução, os esforços haviam sido concentrados na construção do sistema escolar, a preocupação central em 1984 era adequá-lo, com base na "formação para o trabalho e defesa ideológica do socialismo", à nova etapa de desenvolvimento econômico do país. O texto da Reforma realça que a escola, desde o início, se constituiu em prioridade de Estado e continuaria a sê-lo, tal como podemos ler: "Aperfeiçoar a instrução pública é um dos problemas-chave da política do Partido Comunista e do Estado soviético. A reforma do ensino geral e profissional é uma atividade de envergadura nacional e um acontecimento de extraordinária transcendência sociopolítica". (UNIÓN SOVIÉTICA, 1984, p. 8). Em termos teóricos, além de Marx e Engels, três nomes são citados como as principais referências da pedagogia soviética: Lênin, Krupskaya, e Makarenko.

Quanto ao sistema educacional soviético, estava organizado da seguinte forma: préescola, que atendia a maioria absoluta das crianças; escola primária, iniciada aos sete anos de idade; escola secundária incompleta de cinco anos; escola secundária geral e profissional de dois anos. Esta etapa final de dois anos podia ser cursada em escolas secundárias gerais; escolas técnico-profissionais, e centros de instrução média especializada. Somadas, escola primária, escola secundária incompleta e escola geral e profissional perfaziam onze anos de escolaridade obrigatória. Os primeiros nove anos (escola primária e escola secundária incompleta) consistiam na base para o prosseguimento no ensino médio profissional. A correlação entre os egressos desse grau e o prosseguimento para o próximo, segundo o documento, ocorria de acordo com as necessidades da economia nacional, do desejo dos pais e das recomendações dos conselhos pedagógicos das escolas.

Para levar adiante a Reforma, as seguintes questões fundamentais deveriam ser enfrentadas: 1. elevar a qualidade do ensino (nível científico); 2. melhorar a estrutura da formação profissional; 3. aumentar a responsabilidade dos alunos com a qualidade dos seus estudos; 4. elevar o prestígio social dos professores e instrutores da preparação profissional; 


\section{Revista HIIS'THIDIBR On-lime}

Artigo

doi: $10.20396 /$ rho.v17i3.8650923

5. reforçar a base material e técnica dos estabelecimentos de ensino; 6. aperfeiçoar a estrutura da escola de ensino geral e profissional bem como a sua gestão.

Em linhas gerais, quanto à estrutura do sistema, decidiu-se pelo aumento de um ano na escola primária com o objetivo de garantir que as crianças aprendessem "mais a fundo a ler, escrever e contar", além de receberem "hábitos laborais elementares". Gradativamente, elas passariam a ingressar aos seis anos de idade, devendo ser aliviada, nesse grau, a aprendizagem dos fundamentos das ciências. Na escola secundária incompleta (cinco anos), as crianças prosseguiriam o estudo das disciplinas, aprofundando conteúdos dos troncos físico-matemática, químico-biologia e humanidades por meio de classes facultativas. Concluída a nona série, aos quinze anos de idade, teriam cumprido a tarefa de preparação profissional e, "em combinação com as medidas de orientação profissional", estariam criadas as condições que lhes facilitariam a escolha da futura profissão. A partir do décimo ano (escola secundária geral e profissional de dois anos), a preparação profissional previa a "aprendizagem de profissões massivas, necessárias para a produção de bens e outras esferas" contando com escolas de ensino médio especializadas, tais como pedagógicas e médicas, com a finalidade de preparar especialistas qualificados para os escalões primários da indústria, do ensino, da saúde, da cultura, e da esfera de serviços públicos. A todos os jovens, devia ser dada "a possibilidade de aprender uma profissão antes de começar a sua vida laboral" e, de acordo com o texto, a longo prazo isso levaria à aproximação e unificação de todas as escolas de ensino geral e profissional, constituindo-se na maior encarnação das "ideias leninistas sobre uma escola geral, laboral e politécnica". Quanto aos jovens que não tivessem concluído seus estudos de "instrução média" (UNIÓN SOVIÉTICA, 1984, p. 5), deveriam cursar esse grau "sem abandonar o trabalho" cursando turnos alternativos.

A melhoria do ensino geral e profissional, de acordo com a Reforma, criaria iguais condições para o ingresso dos seus concluintes nos centros de ensino superiores, abrindo novas possibilidades para se aperfeiçoar a preparação de especialistas com instrução superior. Previu-se, ademais, a necessidade de se desenvolver a experiência de preparação de especialistas com instrução superior abreviada.

Considerando as necessidades econômicas da União Soviética, a intenção da Reforma foi unificar e reorganizar os diversos tipos de ensino técnico-profissionais " [...] em um só tipo denominado Escola Tecno-Professional média (secundária) com as correspondentes seções de profissão, formas e períodos de instrução". (UNIÓN SOVIÉTICA, 1984, p. 5). Essa escola deveria se especializar na preparação de trabalhadores para todos os ramos da economia nacional, tendo como base as indústrias, empresas, obras e organizações, enquanto no campo estariam adjuntas às agroindústrias distritais, sovkoses, kolkoses e empresas ligadas às fazendas. A relação entre as empresas matriciais e as escolas técnico-profissionais seria regida pelo Conselho de Ministros da URSS, ficando explícita, assim, a relação empresa-escola-Estado, que é justificada para prover maior e melhor produtividade da mão-de-obra.

O trabalho é a palavra-chave da Reforma de 1984. Ele é mais que um princípio educativo: é o foco de todas as atividades da escola. Consta do começo ao fim do texto e a sua prática é exortada desde a infância, constituindo-se, inclusive, em um dever dos pais ensinar o trabalho doméstico aos seus filhos. Eles são chamados a elevar o prestígio da escola e dos professores, a "educar os filhos no espírito do respeito e amor ao trabalho preparando- 
os para atividades socialmente úteis". A expressão "trabalho socialmente útil" está relacionada à função social da instrução. Lê-se que "o padrão de produção, segundo os melhores modelos mundiais exigem do jovem que começa a sua vida profissional trabalhador, especialista ou engenheiro - a instrução mais avançada, o mais alto desenvolvimento intelectual e físico, conhecer a fundo os fundamentos tecno-científicos e econômicos da produção, uma atitude consciente e criadora no trabalho". A escola "há de formar, instruir e educar a juventude" garantindo-lhe um alto nível de conhecimentos imprescindíveis para o prosseguimento de estudos em centros de ensino superiores e, ao mesmo tempo, orientando-a para o trabalho socialmente útil na economia nacional". (UNIÓN SOVIÉTICA, 1984, p. 7). O documento é enfático nesse princípio, insistindo em que qualquer que fosse o destino dos egressos da escola, necessitariam dos hábitos de trabalho em qualquer atividade. "A combinação dos estudos com o trabalho produtivo pressupõe a incorporação dos alunos - iniciando desde os primeiros graus - ao trabalho sistemático, organizado conforme sua idade e suas forças e socialmente útil, trabalho verdadeiro, necessário à sociedade". Essas medidas específicas relativas ao trabalho e às profissões, ou seja, até que ponto a escola se tornaria, ou não, mais "técnica" com a Reforma de 1984, nos remetem brevemente às considerações de Franco Cambi, para quem, de 1927 a 1930, houve uma "politecnização" da escola, e no período de Josef Stalin, que governou de 1924 a 1953, voltou-se a uma escola de cultura, embora mais controlada ideologicamente.

Não é nosso propósito aqui desenvolver considerações teóricas sobre a relação entre educação e trabalho e nem mesmo cotejar as proposições do documento de 1984 com a Resolução de 1919, que estabeleceu “[...] plena realização dos princípios da escola única do trabalho [...] estreita ligação do ensino com o trabalho socialmente produtivo, que prepare membros plenamente desenvolvidos para a sociedade comunista". (MANACORDA, 1989, p. 314-315). Nosso objetivo é mostrar, por meio do texto da Reforma, o modo pelo qual a escola soviética praticou essa relação. Sendo assim, apresentamos a seguir a função de cada etapa da escolaridade no que diz respeito ao trabalho: 1. "Os alunos da escola primária devem dominar as técnicas elementares de trabalho manual com diversos materiais, necessários na vida cotidiana, nos cultivos agrícolas, na reparação e manutenção do material didático"; 2 . $\mathrm{Na}$ escola secundária incompleta, "recebem uma preparação mais profunda para o trabalho, adquirindo conhecimentos e hábitos de trabalho com metais, madeira, familiarizando-se com os fundamentos da eletrônica". A partir do oitavo ano, os alunos aprendem e "trabalham integrando brigadas produtivas". 3. Na escola secundária geral (décimo e décimo primeiro anos), "[...] se organiza a instrução para o trabalho de profissões mais correntes, levando em consideração a sua necessidade em regiões concretas". (UNIÓN SOVIÉTICA, 1984, p. 6).

Para elevar a qualidade do ensino, foram previstos, essencialmente, conhecimentos sólidos e profundos das ciências e visão de mundo materialista. Além disso, os seguintes pontos foram destacados para o aperfeiçoamento da qualidade da instrução: 1. rever o volume de conteúdos das disciplinas, a sobrecarga dos programas de estudos e dos manuais, retirando-lhes o material excessivamente complicado ou secundário; 2 . expor com a máxima clareza as concepções básicas e as ideias-chave das disciplinas estudadas; 3. melhorar a organização da formação laboral, a preparação e a orientação profissional no conteúdo da instrução; 4. prestar maior atenção às aulas práticas e de laboratório, à exposição das leis da física, química e biologia e outras ciências; 5 . dotar os alunos com conhecimentos e hábitos do uso de computadores modernos, assegurando o amplo uso de computadores no processo 
Artigo

doi: $10.20396 /$ rho.v17i3.8650923

de ensino; 6. determinar o volume ideal de conhecimentos e hábitos que os alunos deveriam assimilar em cada disciplina e grau.

Relacionadas às proposições sobre a melhoria do ensino, são feitas recomendações sobre o método ativo ${ }^{17}$. Provavelmente essa menção esteja ligada ao fato de que na época stalinista (1924-1953), o controle estatal recrudesceu e os elementos de ativismo tenderam a desaparecer. Assim, a Reforma de 1984 previu a necessidade de se "aplicar mais amplamente os métodos ativos" a fim de melhorar a qualidade do ensino, "imprimir mais praticismo nas aulas erradicando a superficialidade e o esquematismo" aspecto este relacionado à urgente medida que deveria ser tomada para melhorar os manuais escolares. Ademais, determinouse a redução do número de alunos nas classes até chegar a trinta crianças do primeiro ao décimo ano e a vinte e cinco a partir do décimo ano. Relacionada a essa medida, foi indicada a necessidade de atualizar os manuais didáticos, que deveriam ser elaborados pelos melhores professores, especialistas e cientistas de renome, ampliando as suas potencialidades gráficas. Esses livros de textos deveriam conter "elevado conteúdo ideológico e cientifico, brevidade, exatidão, clareza e fluidez de redação além de aperfeiçoamento do aparato metodológico". Apesar desse controle ideológico, na mesma página o texto exorta pais e professores a ajudarem os filhos a adquirirem a faculdade "de pensar por si próprios".

Segundo as expectativas do Partido, o êxito da Reforma dependeria em alto grau dos professores, de sua firmeza ideológica, profissionalismo e cultura erudita. O "professor popular" (da escola), é enaltecido como o artífice do mundo cultural do jovem. Essa profissão, "a mais nobre e difícil", requeria, segundo o documento, "constante criatividade, infatigável trabalho intelectual, enorme generosidade humana, amor às crianças e fidelidade ilimitada ao seu trabalho". Com seu "abnegado trabalho de formação de novas gerações", os professores, desde a campanha de alfabetização e construção do sistema escolar, gozavam do "mais profundo respeito do nosso povo" e se constituíam em "pilar do nosso Partido e da educação da juventude" Parafraseando Lênin, a Reforma enfatiza que o professor deveria ser colocado em "tão alto nível como jamais havia estado ou pudesse estar na sociedade burguesa". Medidas para sua melhor formação, como "boa preparação prática" e reformulações programáticas das escolas pedagógicas superiores, médias especializadas e universidades são também determinadas, devendo todas elas "ajustar os planos às exigências da vida”. (UNIÓN SOVIÉTICA, 1984, p. 7). Além de indicar a necessidade de aumentar os salários, a Reforma reconhece como uma das tarefas mais importantes das instituições formadoras a seleção de novos professores e instrutores e, para isso, solicita o envio, pelo Konsomol (Juventude Comunista), de jovens egressos das escolas médias. Considerando a escola como uma das maiores responsabilidades do Partido, a Reforma recomenda que os professores fossem informados sobre os problemas mais importantes da sua política interna e externa e que não fossem envolvidos em tarefas alheias ao ensino.

Para o desenvolvimento "harmonioso e multifacético do indivíduo", a Reforma recomendou enfoque integral do trabalho educativo visando "todas as vertentes da educação comunista: ideo-política, profissional, moral, estética e física". Além da obrigatoriedade de exercícios físicos diários nas escolas (ginástica), no tempo livre e nas seções desportivas, destacou a necessidade de "melhorar o ensino artístico, a formação estética, desenvolver o sentido do belo, ensinar finos gostos estéticos, desenvoltura para compreender e valorizar as obras de arte, os monumentos históricos e arquitetônicos, a beleza e a riqueza da Pátria". 
Para isso, deveriam ser melhor aproveitadas as possibilidades oferecidas pelas disciplinas da literatura, música, artes plásticas e estéticas devido à sua grande força instrutiva e educativa. História e ciências sociais, por sua vez, são explicitamente relacionadas à função ideológica. Textualmente, se lê: "Nas aulas de história, ciências sociais, literatura e outras disciplinas, há que se ensinar a arte de saber defender as convicções comunistas, a intransigência frente ao parasitismo e o consumismo [...] considerar imprescindível o aumento de tempo de estudo das ciências sociais e redigir para todos os tipos de escolas médias um único manual de ciências sociais". (UNIÓN SOVIÉTICA, 1984, p. 5).

Outro aspecto marcante da escola soviética foi reafirmado pela Reforma: a sua função para a formação do sentimento patriótico. Os seguintes trechos ilustram essa diretriz: "Acentuar a educação dos alunos no espírito do patriotismo soviético (...); usar mais no trabalho educativo os símbolos do Estado soviético: o escudo, a bandeira e o hino da União Soviética"; "A formação patriótico-militar dos alunos deve orientar-se para a preparação para as Forças Armadas, educá-los na fidelidade ao Exército Soviético; inculcar-lhes o sentimento de orgulho por pertencer à Pátria socialista e estar sempre dispostos a defendêla"; "A escola é obrigada a educar de forma a que a pessoa sinta a necessidade de viver e atuar de acordo com os princípios da moral comunista, de respeitar estritamente as regras da vida em sociedade e as leis soviéticas". (UNIÓN SOVIÉTICA, 1984, p. 5).

Apenas sete anos separam a Reforma educacional de 1984 do fim da União Soviética (1991). No entanto, nenhum sinal de crise política ou de insatisfação social contra o regime transparece no texto. Ao contrário, o documento é enfático na afirmação sobre a superioridade do socialismo e demonstra grande apreensão "com as manobras das forças agressivas do imperialismo que atacam o socialismo e depositam suas esperanças na inexperiência política dos jovens". (UNIÓN SOVIÉTICA, 1984, p. 4). Neste ponto, dois aspectos chamam a atenção: o primeiro diz respeito à percepção de que o perigo maior que rondava o socialismo vinha de fora; o segundo é a menção a uma juventude politicamente inexperiente depois de setenta anos de socialismo.

Como afirmou Gorbachev em seu discurso de despedida aqui citado, se a sociedade soviética ainda não havia aprendido a usar a liberdade, podemos relacionar esse fato à falta dela ao longo das sete décadas de Revolução e não exclusivamente ao antigo passado czarista. $\mathrm{O}$ fato de ela ter acontecido em um país que vivia sob esse regime e por isso não dispunha de representações políticas, caracterizando, ao contrário, uma sociedade civil fraca do ponto de vista de sua organização, não pode justificar que, depois, tenha sido instituído um único partido político. Inclusive porque, no início da Revolução, os grupos internos partidários eram vigorosos e também estavam comprometidos com ela, apesar de, na sequência, terem sido classificados de contrarrevolucionários e até de traidores. Da mesma forma, é descabido supor que não houvessem outras formas de pensar o mundo se lembrarmos, por exemplo, da força cultural exercida secularmente pela Igreja Ortodoxa Russa. A forte religiosidade que remontava ao Império Russo, desde o século IX, constituiuse em tenaz oposição, mesmo que reprimida, à concepção de mundo vigente desde 1917.

De acordo com ela, a formação dos jovens é enfatizada pela Reforma nos seguintes termos: "Crescem as exigências sobre a formação ideo-política da juventude, a sua cosmovisão marxista-leninista". A exigência sobre essa visão de mundo oficial está expressa em vários pontos do documento que citamos a seguir: "A tarefa mais importante da escola 
Artigo

doi: $10.20396 /$ rho.v17i3.8650923

soviética reside em proporcionar à juventude profundos e sólidos conhecimentos dos fundamentos das ciências [...] dar-lhes uma cosmovisão materialista". "A base mais firme da educação comunista dos alunos é a formação em uma cosmovisão marxista-leninista. Importa que [...] se ensinem aos alunos concepções materialistas sólidas, pontos de vista ateus, explicar acertadamente os fenômenos da natureza e da sociedade e atuar de acordo com nossos princípios conceituais". (UNIÓN SOVIÉTICA, 1984, p. 4).

De um lado, a revolução técnico-científica inaugurava novas formar de pensar e de viver, de outro, a participação dos jovens na União Soviética era permitida em três instâncias políticas vinculadas ao Partido: Outubrinos (para as crianças); Pioneiros (para os adolescentes); Konsomol (para os jovens). Eram consideradas organizações sociais necessárias para a "formação comunista" e também "pilares dos coletivos pedagógicos". Delas muito dependia a "formação comunista dos alunos", por isso a Reforma exorta o apoio às suas iniciativas e atividades, lembrando o quão importantes haviam sido para Nadezhda Krupskaya e Anton Makarenko. (UNIÓN SOVIÉTICA, 1984, p. 6). Sendo assim, deveriam ser reforçados em cada local os complexos extraescolares, como palácios e casas de pioneiros, clube de jovens técnicos, naturalistas, excursionistas, escolas de iniciação desportiva, musicais, de pintura e coreográficas, bibliotecas infantis e acampamentos de pioneiros. "Educar desde a infância mais tenra no sentido do coletivismo, de ser exigente consigo mesmo e para com os outros, valorizar a honradez, a sinceridade, generosidade, firmeza, e tenacidade". Quanto ao fato de ser uma escola de cultura, lê-se: "Nas escolas, casas de pioneiros, clubes e palácios da cultura devem organizar-se círculos de aficionados à arte prestando sempre atenção ao seu repertório. Combater energicamente a ausência de ideologia, a vulgaridade e a produção cultural de baixa qualidade no meio juvenil". (UNIÓN SOVIÉTICA, 1984, p. 6).

Ao fecharmos essa análise, realçamos que a escolaridade na União Soviética não apenas foi garantida a todos; ela foi obrigatória. Esse é um aspecto distintivo da educação soviética que está profundamente vinculado aos objetivos da industrialização e da própria construção do socialismo. A rápida alfabetização, a escola primária e a secundária foram universalizadas em meio a obstáculos de toda ordem, originados por fatores objetivos e subjetivos. Além disso, houve tensão entre os interesses do coletivo e os dos indivíduos. Todos estavam na escola, mas a trajetória dos alunos dependia mais de seu pertencimento às organizações extraescolares e das avaliações dos conselhos pedagógicos do que de suas próprias aspirações. Dependia também da região geográfica em que viviam, já que as escolas, apesar de currículos comuns, não conseguiam manter exatamente o mesmo nível de qualidade na oferta de suas atividades. Em nossa vivência, pudemos constatar que um indicativo claro da universalização da escola e do acesso aos bens culturais na União Soviética foi a expectativa de alto horizonte sobre a realização pessoal gerada por essa igualdade: as meninas sonhavam ser bailarinas do Balé Bolshoi enquanto os meninos, astronautas. Como equacionar desejos individuais com as necessidades da economia nacional? Se, como escreveu Marx, a história é um constante processo de contradição e transformação, esse era um desafio do socialismo.

\section{CONCLUSÕES}


O exame detalhado sobre o texto da reforma educacional soviética de 1984 nos permite indicar quatro pontos que, em nosso entender, constituem os aspectos conclusivos deste estudo.

O primeiro deles, talvez o mais importante sobre a educação na União Soviética é o fato de que se tratou, em essência, de uma sociedade que, em setenta anos, transitou do analfabetismo em massa para a plena escolaridade. De 1917 a 1984, data da Reforma aqui analisada, o país passou a ser dotado de um sistema universal, estatal e obrigatório. Ao longo dos setenta anos de existência da União Soviética, a instauração e o desenvolvimento do sistema socialista de instrução foram considerados pelo Partido como "um fator importantíssimo da confiança na civilização socialista". De nossa parte, acreditamos que, ao lado da industrialização, a criação do sistema de instrução pública foi a política de maior envergadura da União Soviética. Duas políticas inseparáveis.

O segundo ponto diz respeito a que, essencialmente, a escola soviética foi construída e continuaria a ser fundamentada em dois pilares: o trabalho e a formação ideológica. A "cosmovisão marxista", o ateísmo, e concepção materialista como necessidade para conhecer profundamente as ciências, ao lado da defesa incondicional da "pátria socialista" são claramente enfatizados como requisitos para a formação da juventude. Apesar do seu papel como aparelho ideológico de Estado, ela se manteve sempre como uma escola de cultura.

O terceiro aspecto relaciona-se à constatação de que, após setenta anos de socialismo, a escola soviética estava defasada e não correspondia aos desafios da revolução técnicocientífica, às necessidades da economia nacional e à sociedade do conhecimento. O objetivo da Reforma aqui examinada era exatamente adequá-la a esses desafios do socialismo desenvolvido. No entanto, ela mirou um futuro que não aconteceu. A inesperada extinção da União Soviética em 1991 praticamente coincidiu com a data prevista para a total implementação da Reforma (1984-1990). Sendo assim, essa brusca dissolução inviabiliza o balanço sobre o seu alcance. Mas, ante essa impossibilidade, julgamos ter feito um exercício válido: retornamos ao ponto inicial da construção do sistema escolar soviético tendo o texto da Reforma de 1984 como uma espécie de espelho retrovisor, pois visando o futuro, ela nos apresentou o quadro da escola construída durante os setenta anos da Revolução.

Finalmente, o quarto aspecto conclusivo a que chegamos decorre da comparação entre o texto da Reforma (1984) e o programa de reestruturação (perestroika, 1985). Examinando o objetivo central da segunda, é possível constatar que nem todos os aspectos da reforma escolar correspondiam às necessidades reais da União Soviética naquele momento, necessidades sobre as quais, possivelmente, o País ainda não havia tomado consciência completa em 1984. 


\section{Revista HIIS'TEIDBR On-lime}

\section{Artigo}

doi: $10.20396 /$ rho.v17i3.8650923

\section{ÁLBUM FOTOGRÁFICO}

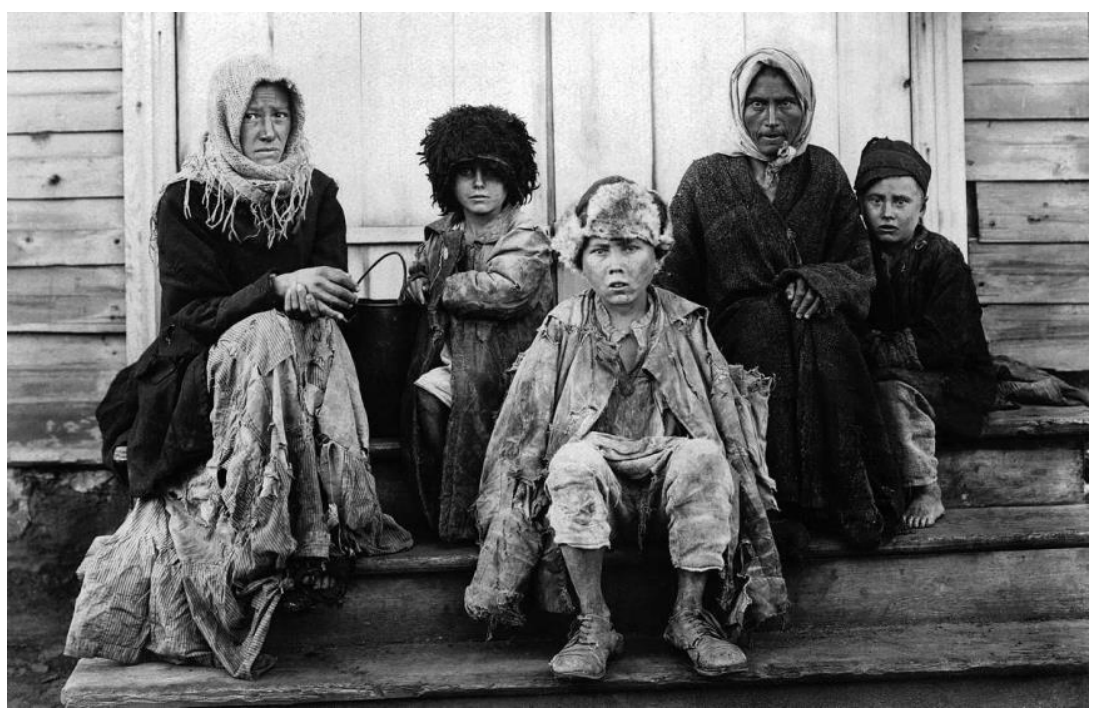

Fotografia 1 - Casa de alojamento, 1921-1922. Chelyabinsk Gubernia.

Fonte: https://russiainphoto.ru. Consultado em: 30/06/2017.

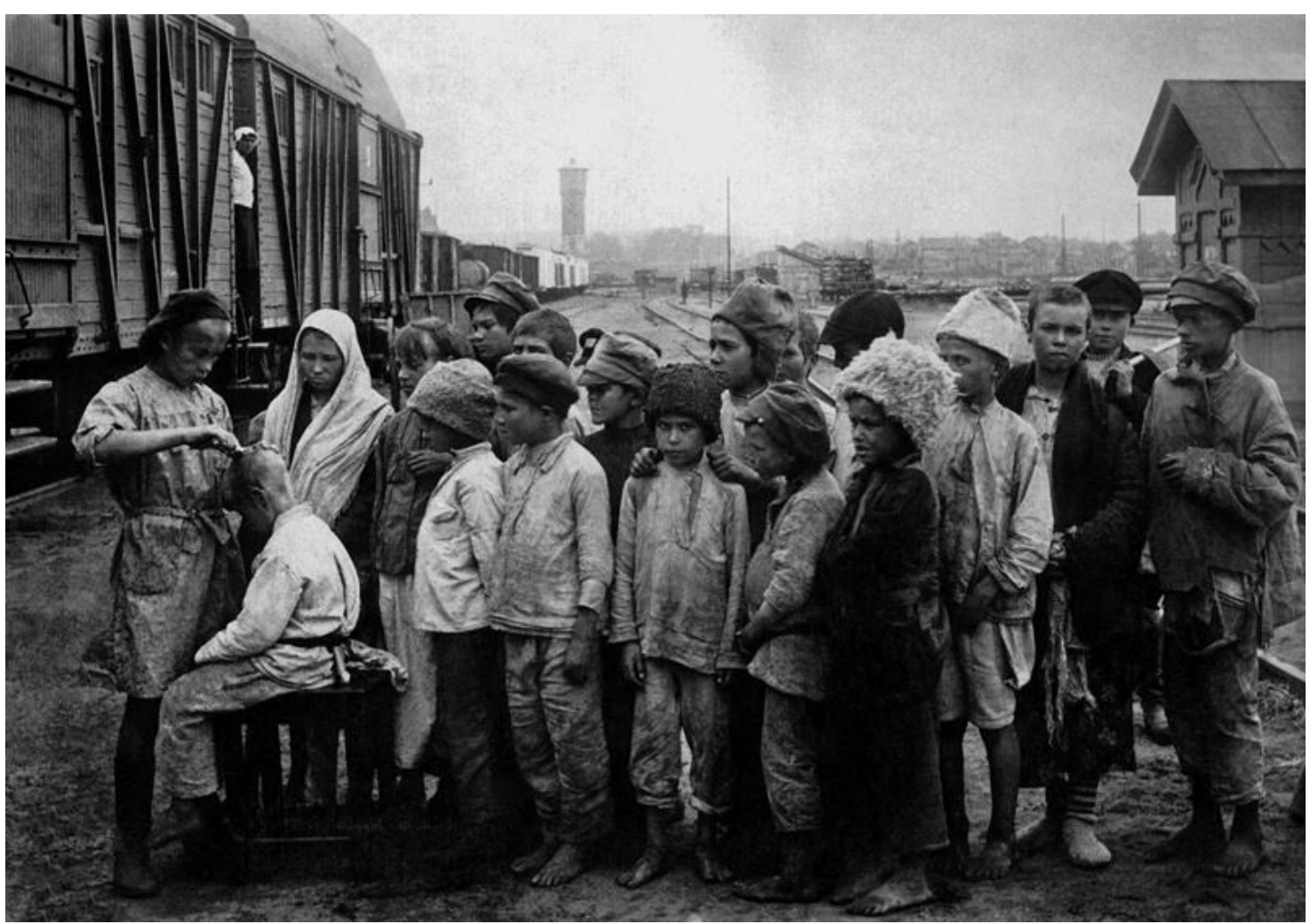

Fotografia 2 - Corte de cabelo de crianças órfãs em áreas assoladas pela fome, início da década de 1920. Fonte: https://russiainphoto.ru. Consultado em: 30/06/2017. 


\section{Revista HIIS'TEIDBR On-lime}

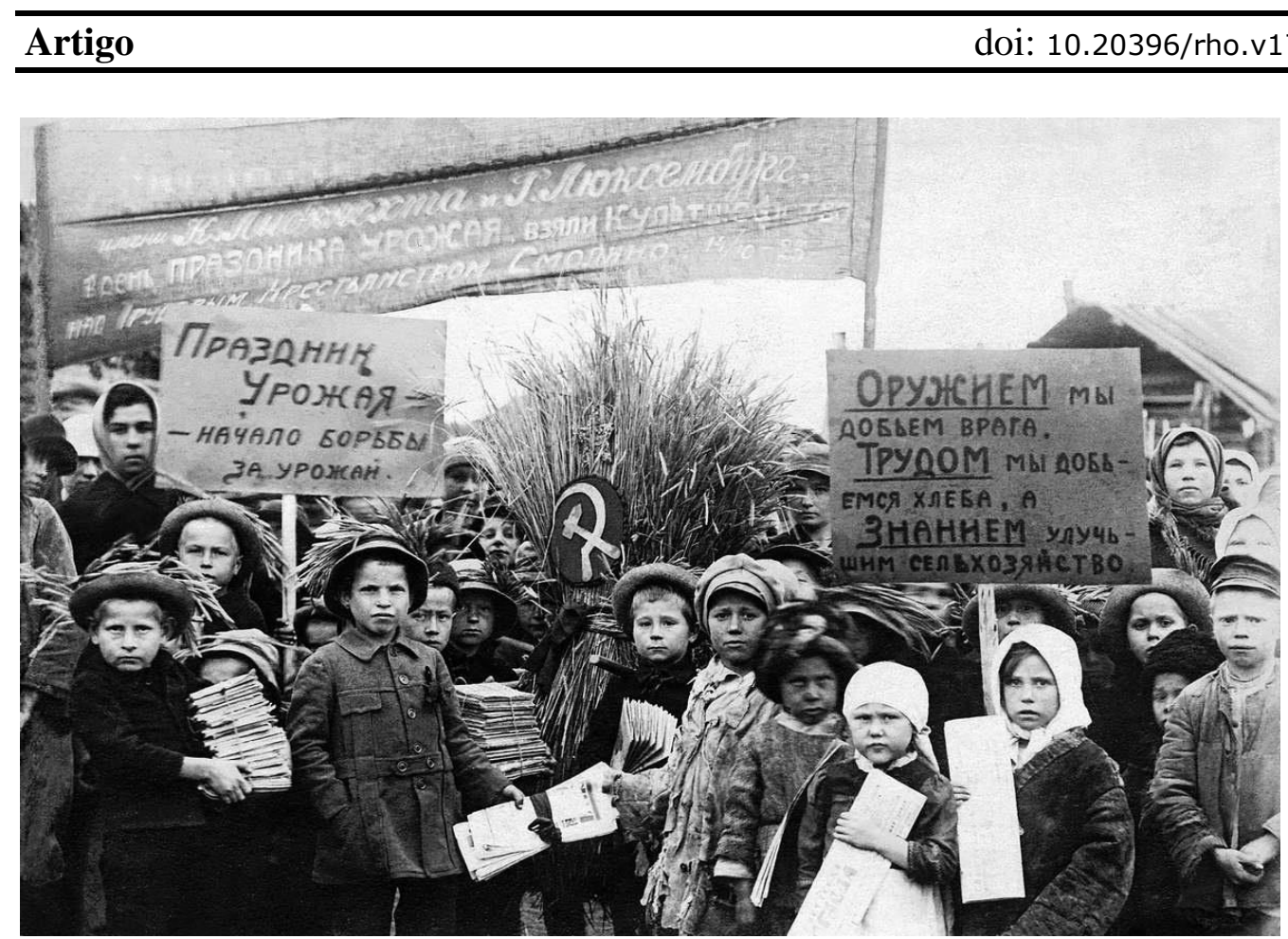

Fotografia 3 - Escola de Trabalho "Karl Liebknecht e Rosa Luxemburgo". Transferência dos filhos de camponeses da aldeia de Smolino; mudança da biblioteca, 1923. Chelyabinsk.

Fonte: https://russiainphoto.ru. Consultado em: 30/06/2017.

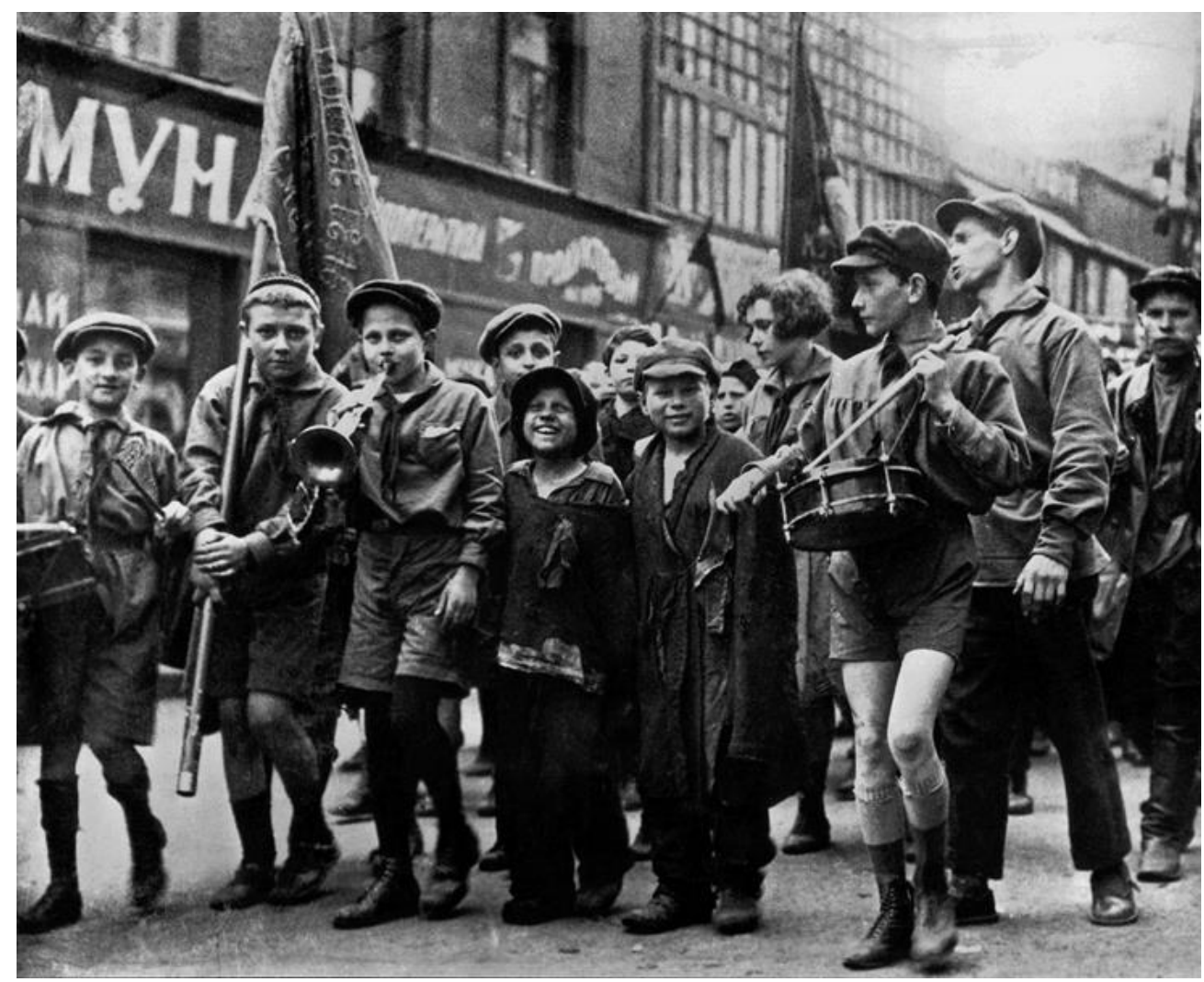

Fotografia 4 - "Pioneiros" (organização dos adolescentes), em manifestação de rua comemorativa ao Primeiro de maio de 1927, em Moscou.

Fonte: https://russiainphoto.ru. Consultado em: 30/06/2017. 


\section{Revista HIIS'TEIDBR (Dn-lime}

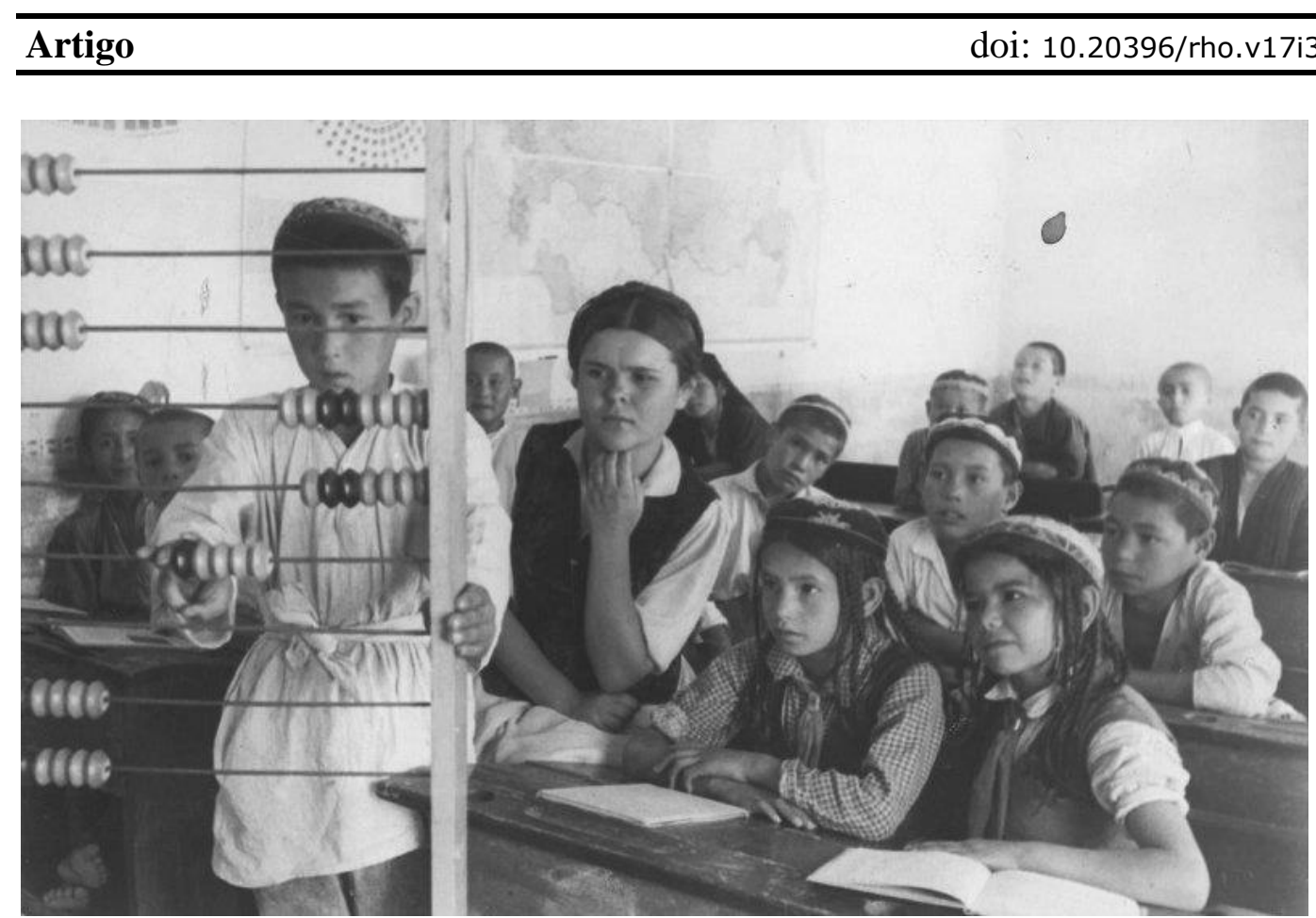

Fotografia 5 - Aprendendo a calcular com o ábaco. Escola da fazenda coletiva “Camarada Stalin", Distrito de Yangikurgan, 1939-1940. Uzbeque (URSS), Região de Fergana.

Fonte: https://russiainphoto.ru. Consultado em: 30/06/2017.

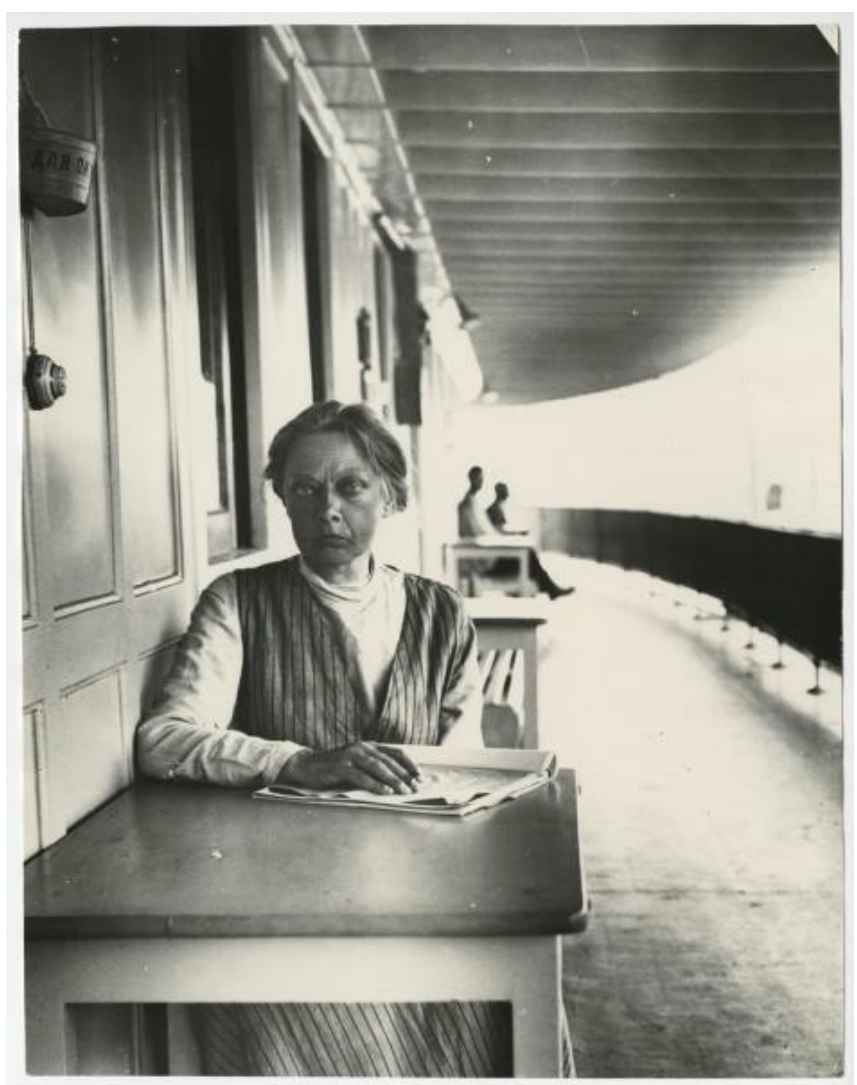

Fotografia 6 - Nadezhda Krupskaya num navio a vapor, dezembro de 1929.

Fonte: https://russiainphoto.ru. Consultado em: 30/06/2017. 


\section{Revista HIIS'TEIDBR (Dn-line}

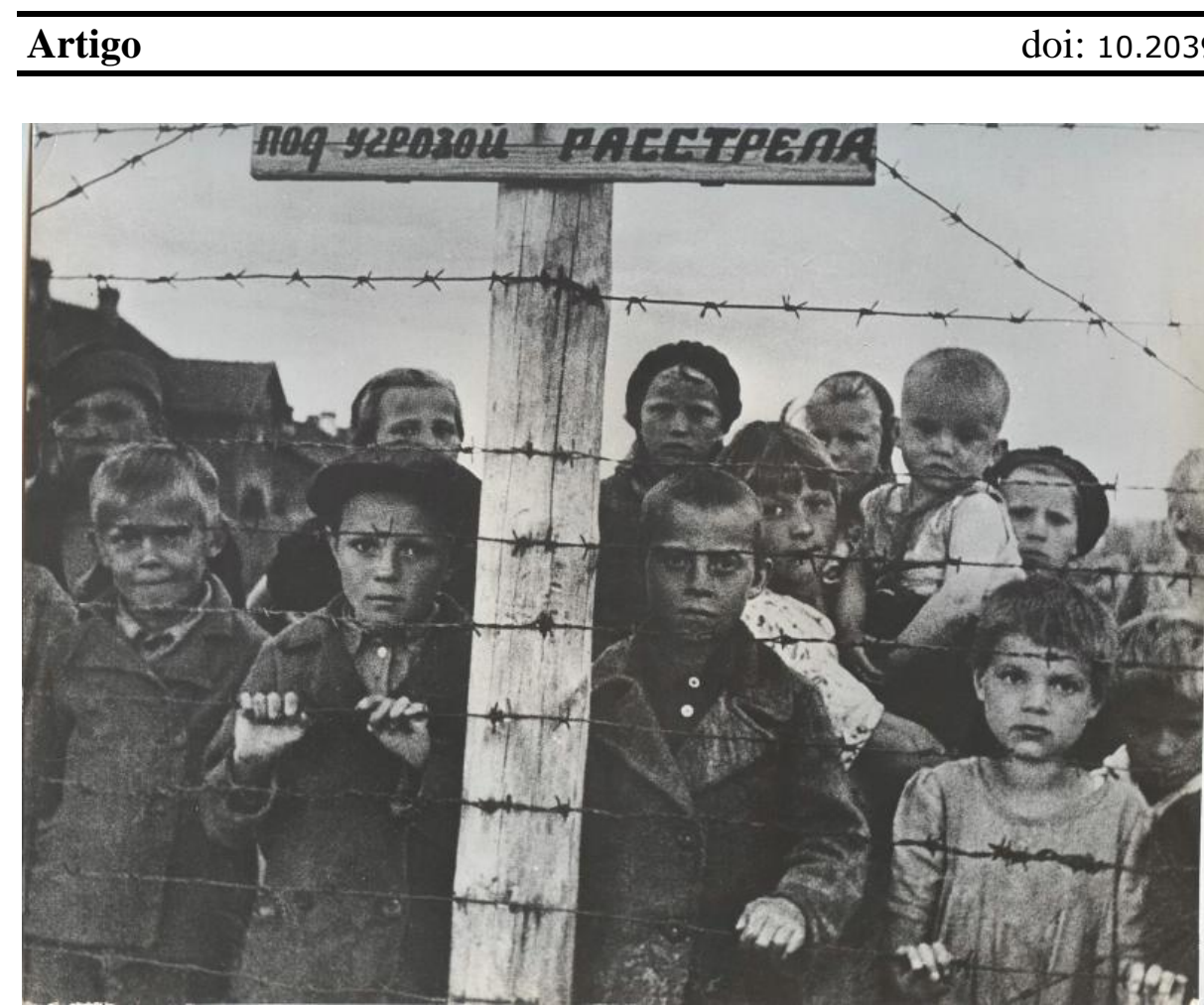

Fotografia 7 - Crianças prisioneiras dos nazistas durante a Segunda Guerra Mundial (28/06/1944), KareloFinlandês (URSS), Petrozavodsk, campo de concentração n. ${ }^{\circ} 6$.

Fonte: https://russiainphoto.ru. Consultado em: 30/06/2017.

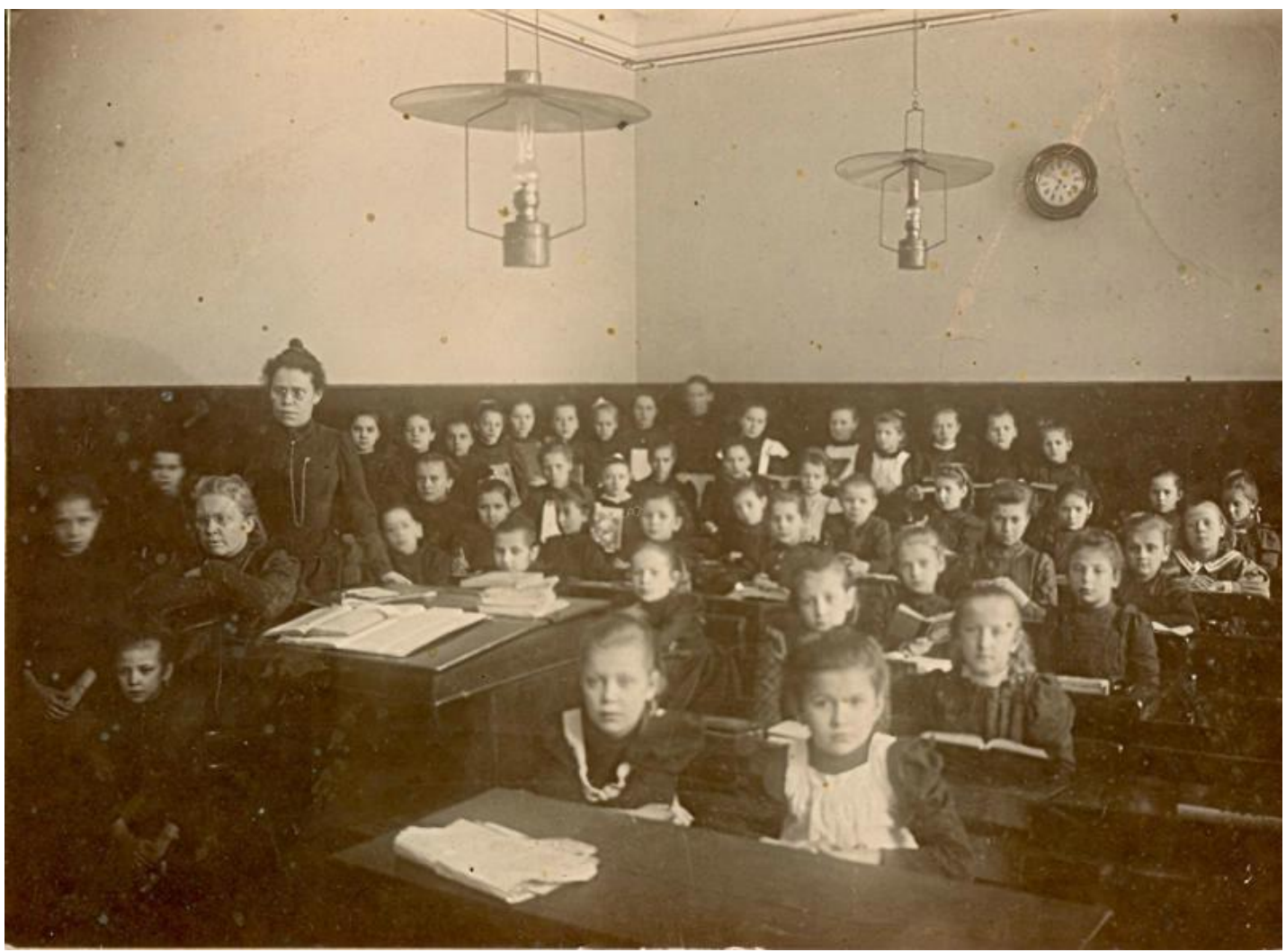

Fotografia 8 - Uma sala de aula, em 1929.

Fonte: https://russiainphoto.ru. Consultado em: 30/06/2017. 


\section{Revista HIIS'TEDIBR On-lime}

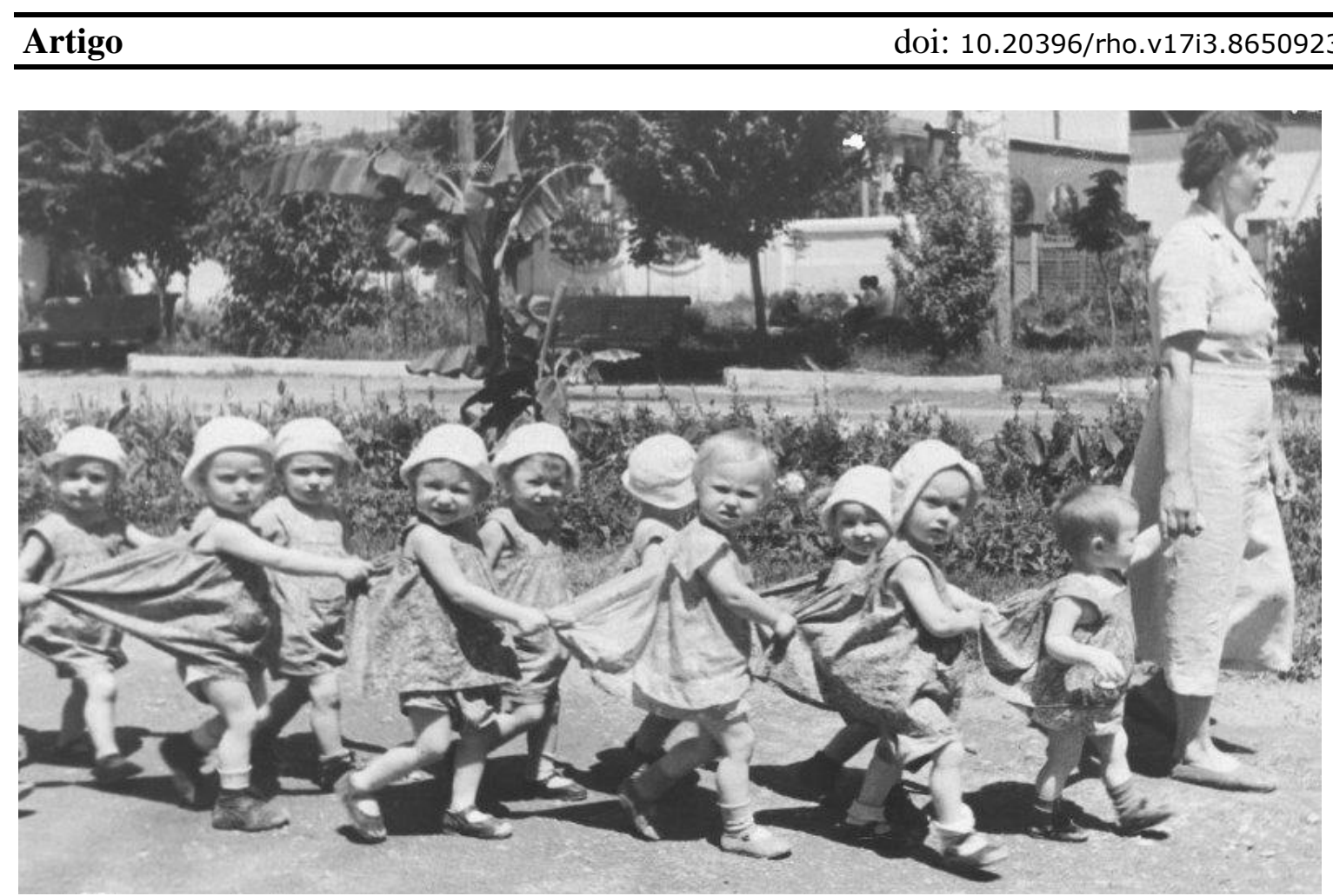

Fotografia 9 - Jardim de infância; uma caminhada. Uzbek (URSS), década de 1930.

Fonte: https://russiainphoto.ru. Consultado em: 30/06/2017.

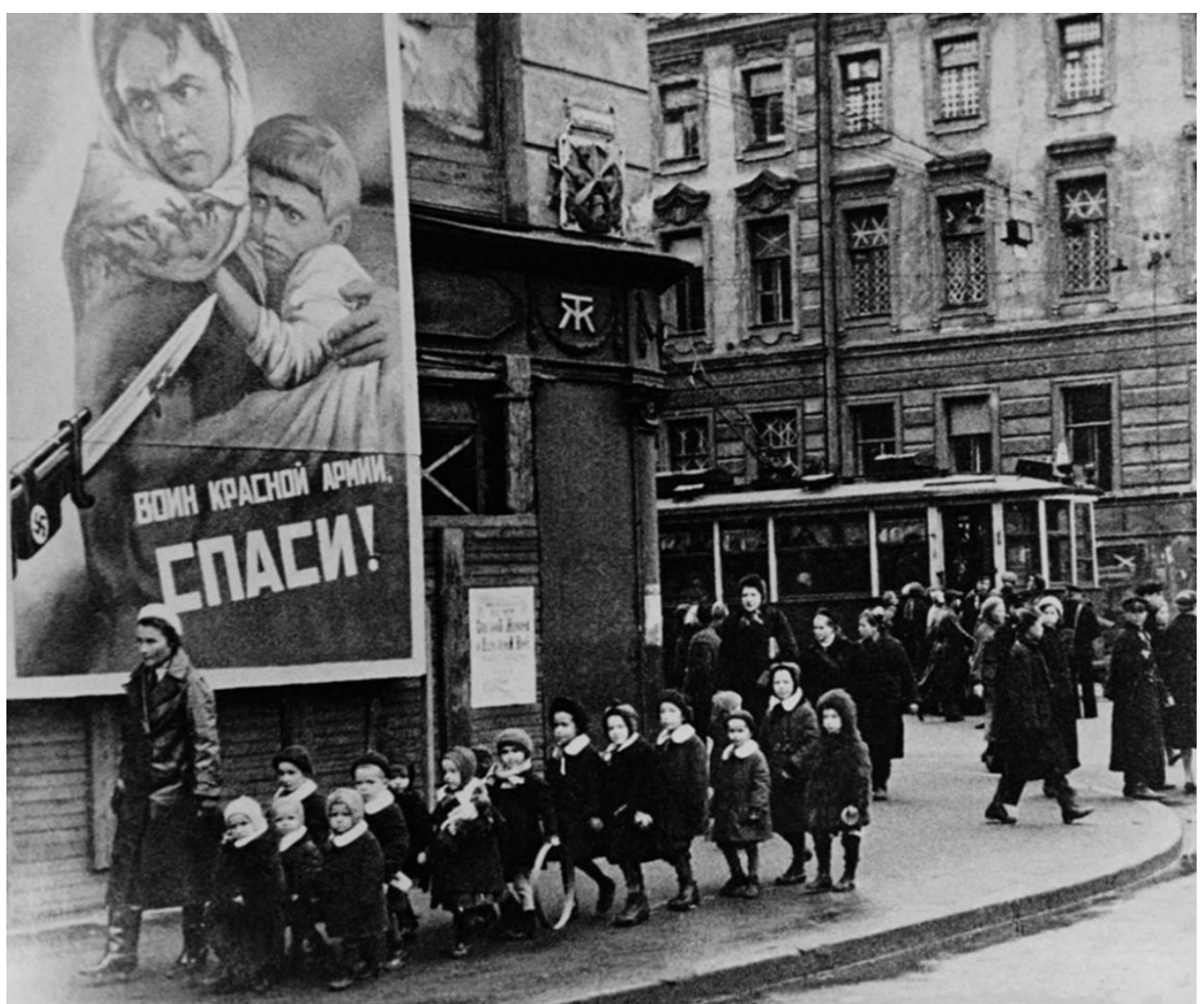

Fotografia 10 - Cidade de Leningrado (hoje São Petersburgo) sitiada pelos nazistas (1942). Fonte: https://russiainphoto.ru. Consultado em: 30/06/2017. 


\section{Revista HIIS'TEIDBR (Dn-lime}

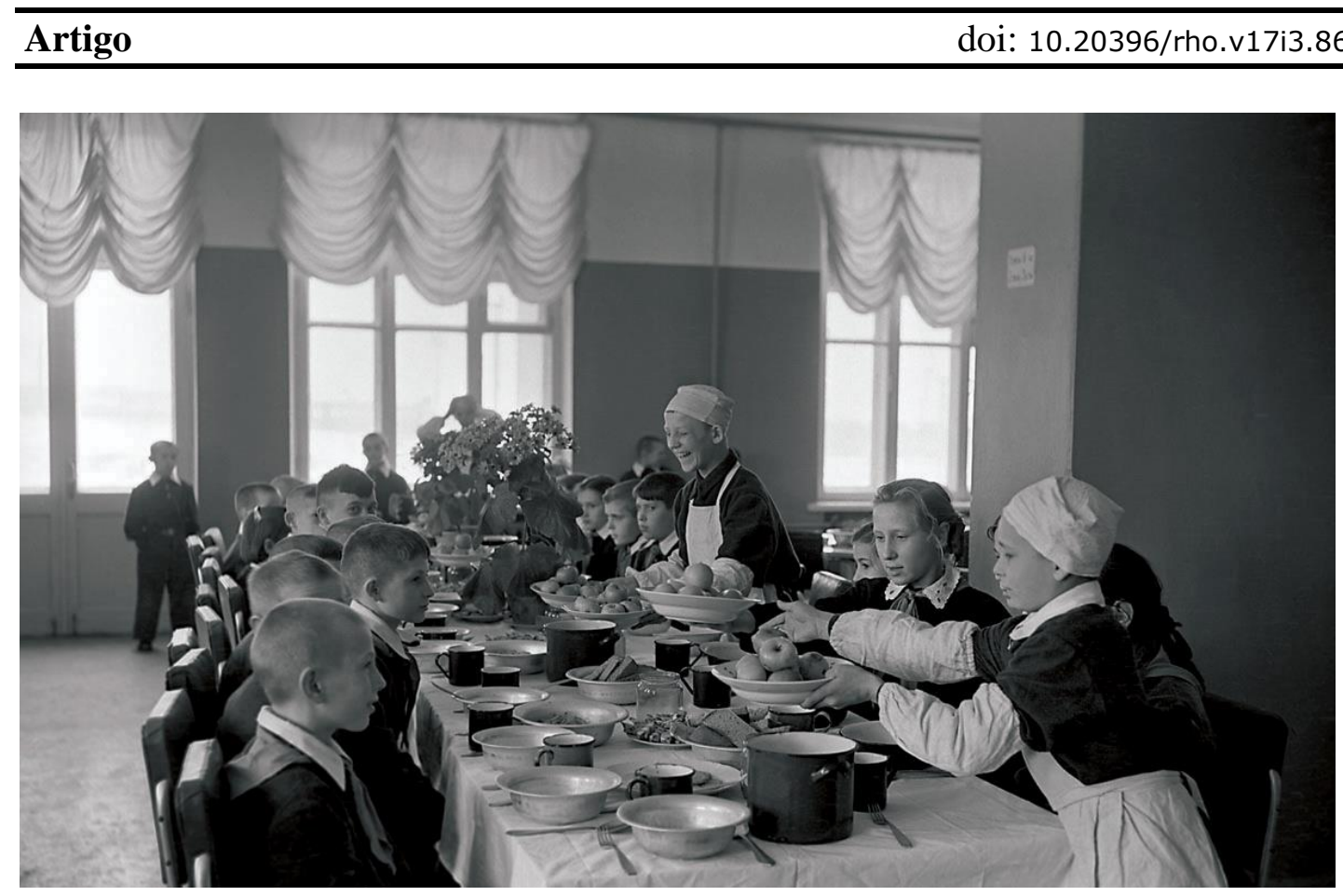

Fotografia 11 - Restaurante escolar (1950-1963). Nas escolas de período integral ou internatos, as crianças, além da educação geral, desenvolviam trabalhos comuns. Nesse internato de Magnitogorsk, à beira do Rio Ural, elas criavam porcos, bezerros, galinhas, coelhos e aprendiam a operar máquinas.

Fonte: https://russiainphoto.ru. Consultado em: 30/06/2017.

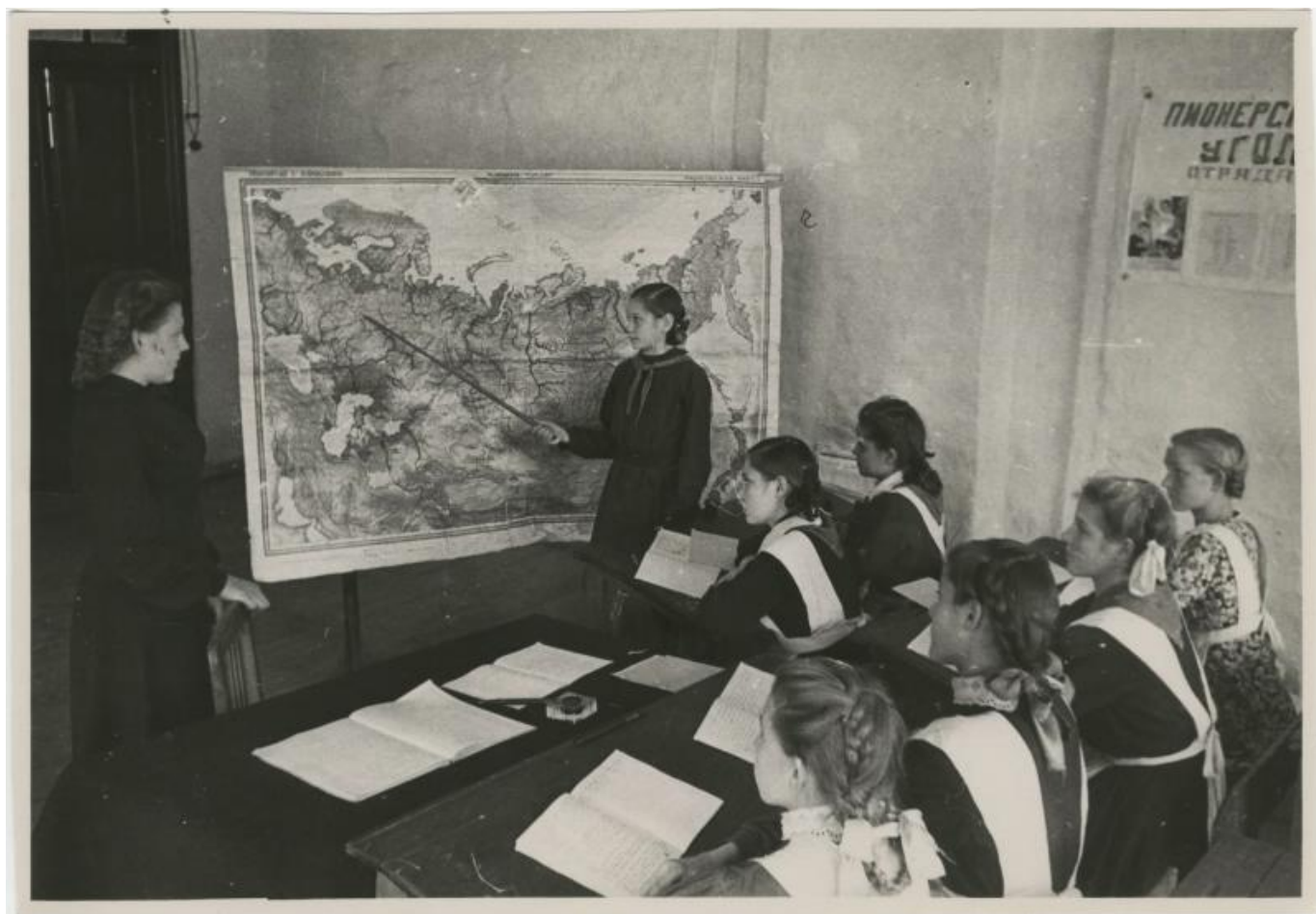

Fotografia 12 - Sala de aula (1954). ]

Fonte: https://russiainphoto.ru. Consultado em: 30/06/2017. 


\section{Revista HIIS'TEDIBR On-lime}

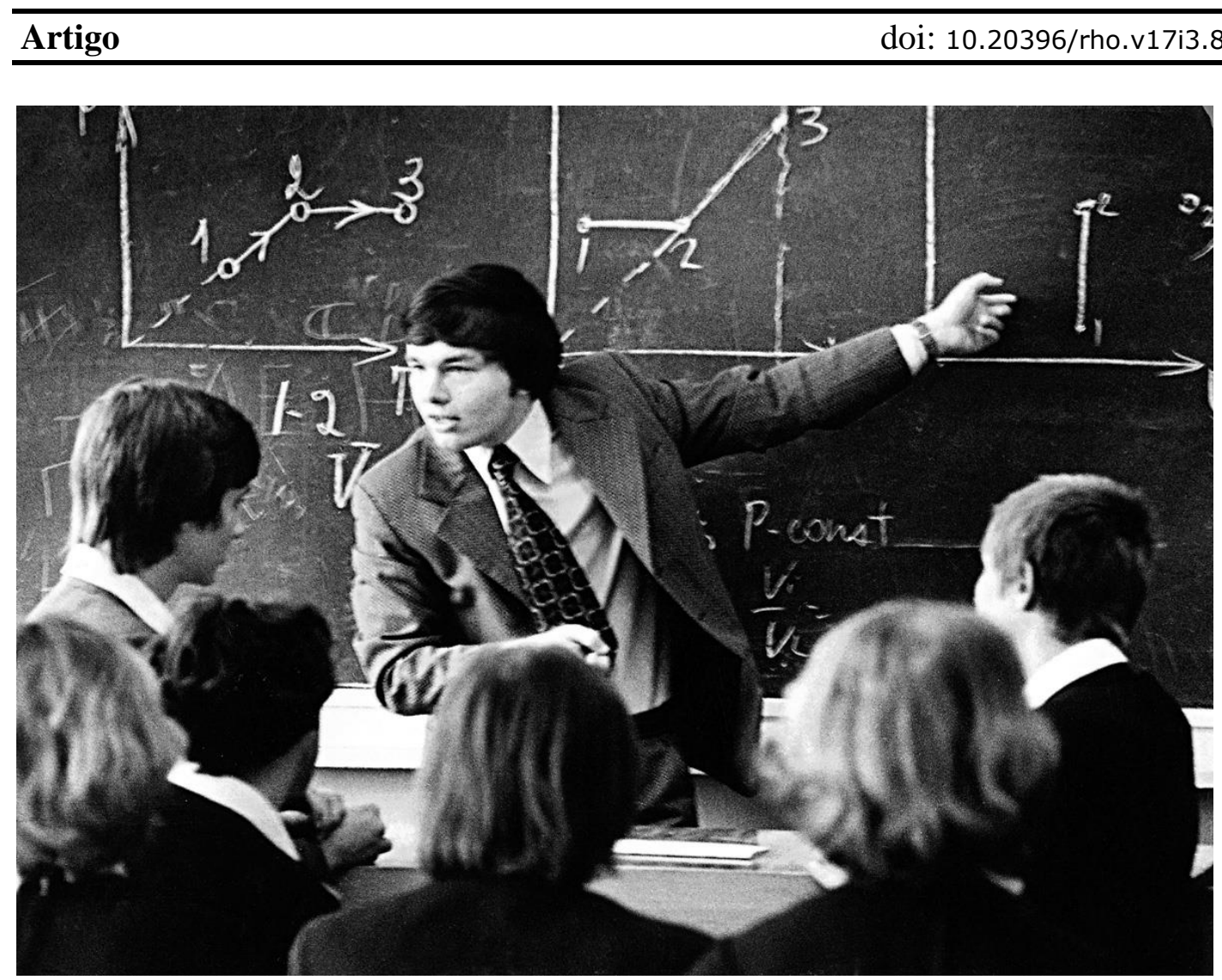

Fotografia 13 - Aula de Física. Professor V. N. Kespikov (1960), Chelyabinsk.

Fonte: https://russiainphoto.ru. Consultado em: 30/06/2017.

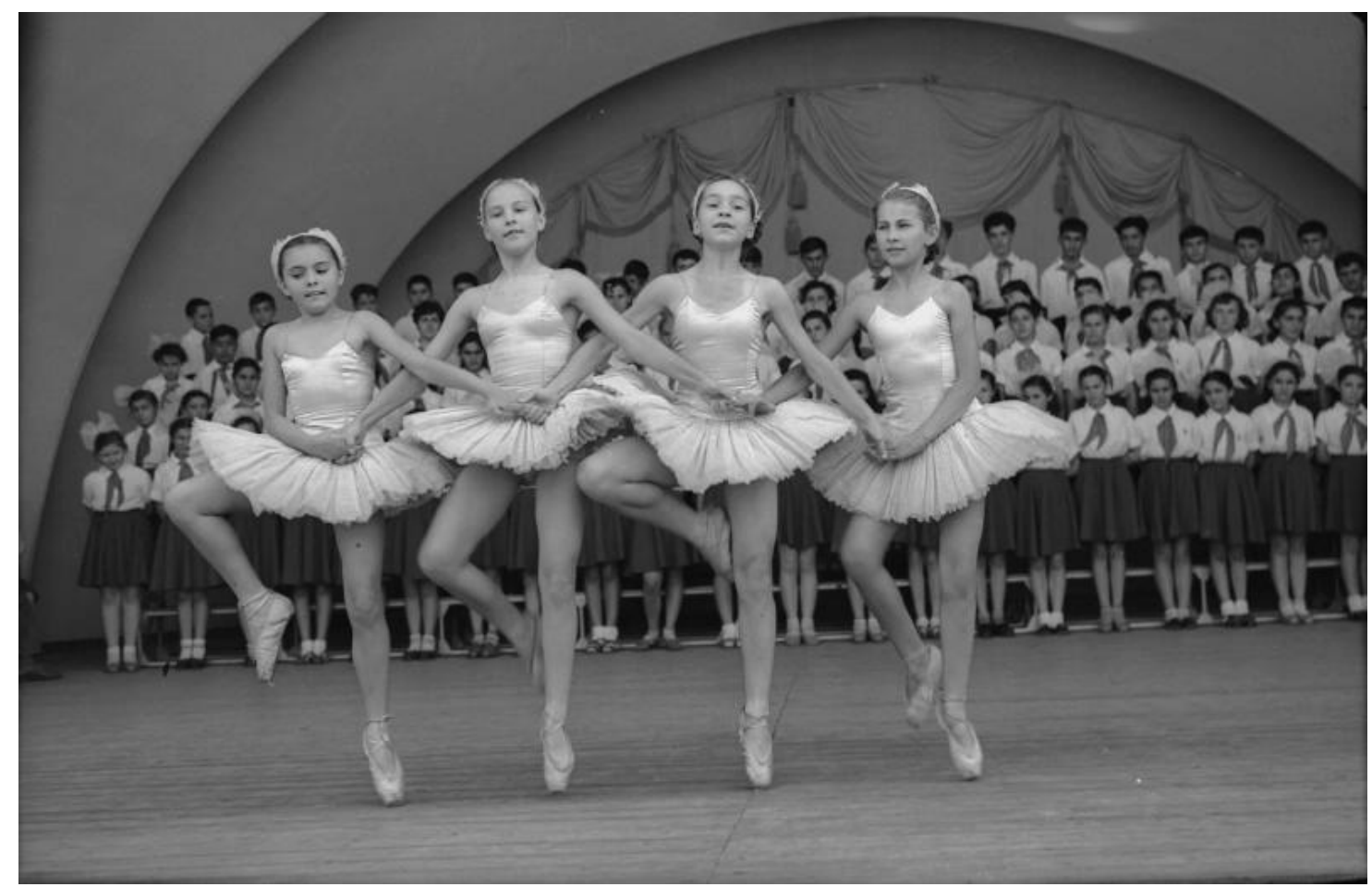

Fototgrafia 14 - Apresentação de alunas de balé em festividade escolar na Sibéria (1958).

Fonte: https://russiainphoto.ru. Consultado em: 30/06/2017. 


\section{Revista HIIS'TEIDBR (Dn-lime}

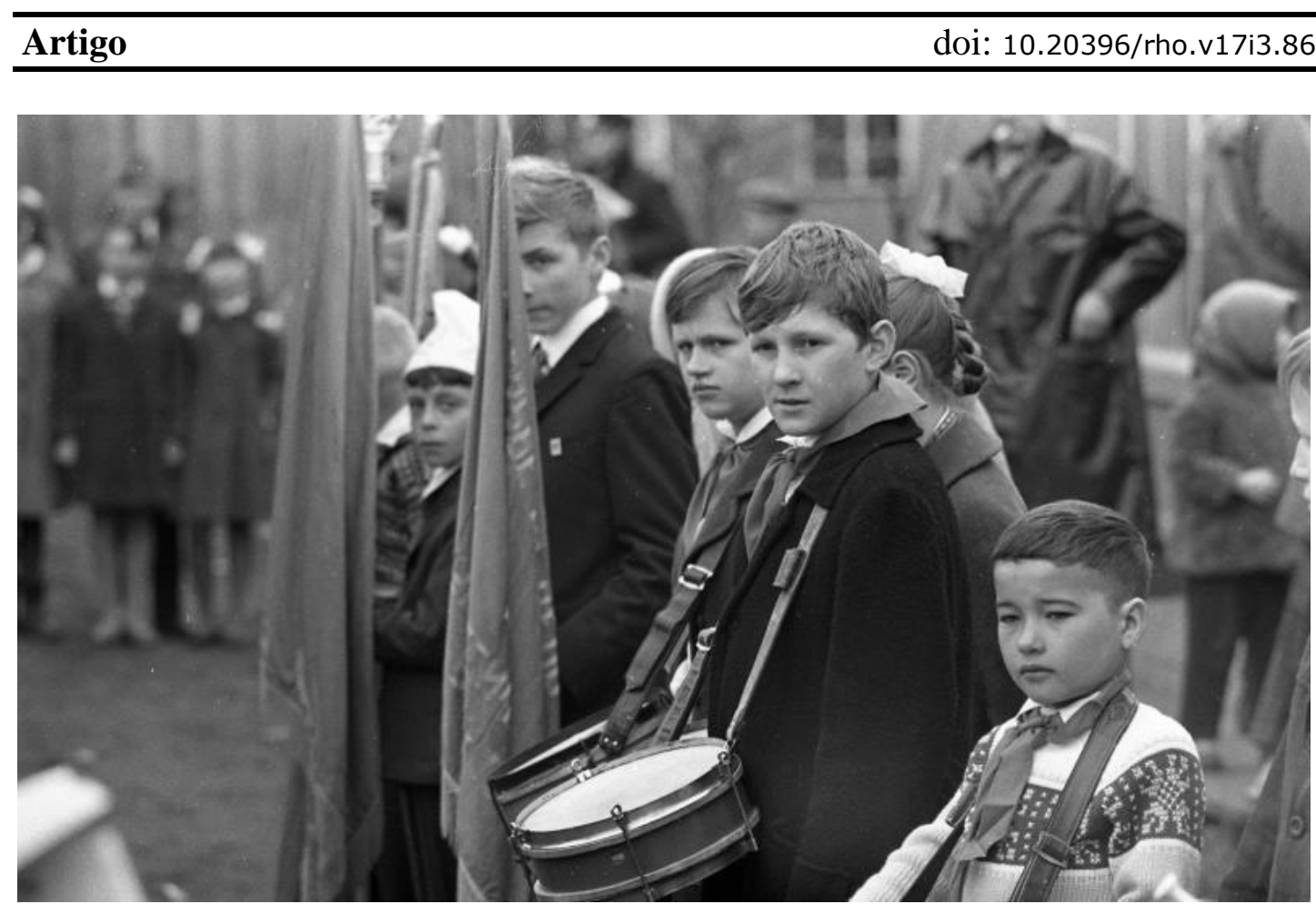

Fotografia 15 - Dia Nacional dos Pioneiros (19. 5. 1968), destacamento na cidade de Yuzhno-Kurilsk (Distrito das Ilhas Curilas do Sul). Nessa data, a juventude soviética realizavaconcertos, desfiles e manifestações que exaltavam os símbolos nacionais. Além disso, coletando sucata, papelão e similares, praticavamas "lições de Lenin" por meio de competições entre unidades escolares ("druzhinami”). Fonte: https://russiainphoto.ru. Consultado em: 30/06/2017.

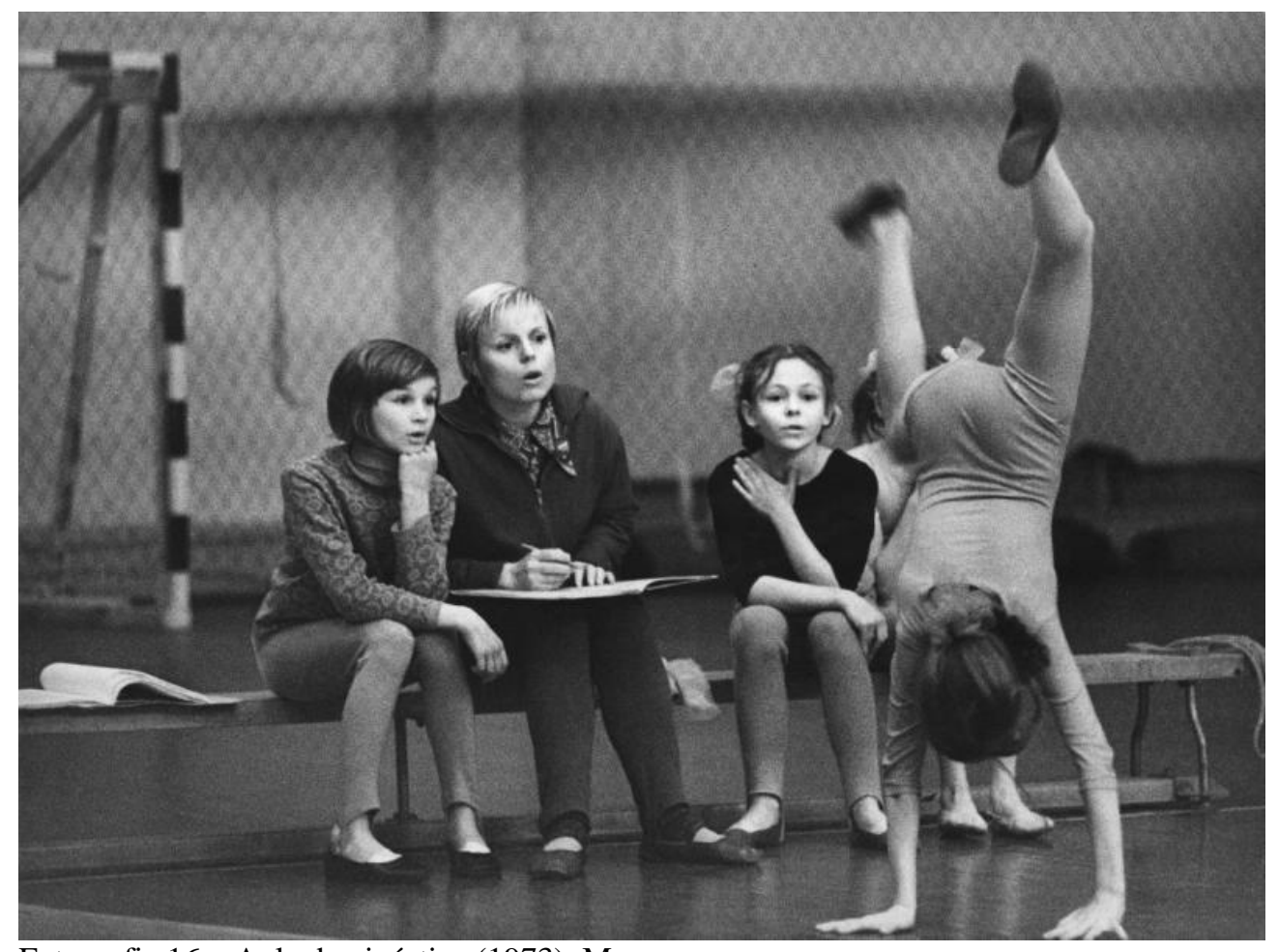

Fotografia 16 - Aula de ginástica (1973), Moscou.

Fonte: https://russiainphoto.ru. Consultado em: 30/06/2017. 


\section{Revista HIIS'TEIDBR (Dn-lime}

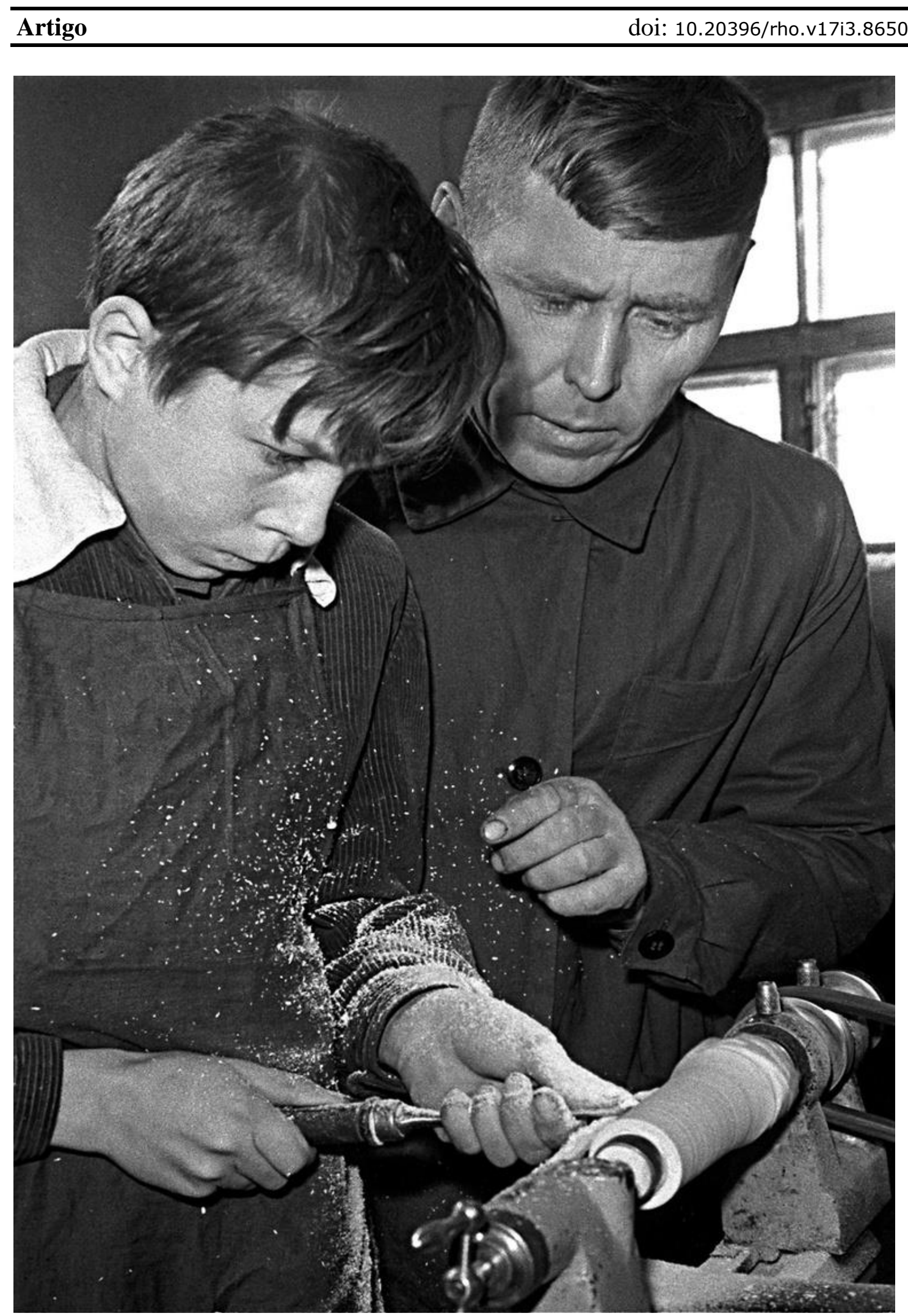

Fotografia 17 - Fazenda estadual "Uysky". Aluno da $6^{\text {a }}$ série A. Butyrnin e o instrutor de trabalho K. V. Vandyshev em atividade nas oficinas escolares durante a década de 1960, região de Chelyabinsk, bairro de Uysk.

Fonte: https://russiainphoto.ru. Consultado em: 30/06/2017. 
Artigo

doi: $10.20396 /$ rho.v17i3.8650923

\section{REFERÊNCIAS BIBLIOGRÁFICAS}

A HISTÓRIA DA RÚSSIA EM FOTOS. Aprendendo a calcular com o ábaco. Escola da fazenda coletiva "Camarada Stalin", Distrito de Yangikurgan, 1939-1940. Uzbeque (URSS), Região de Fergana. 1 fotografia. Disponível em: <https://russiainphoto.ru.>. Acesso em: 30 jun. 2017.

A HISTÓRIA DA RÚSSIA EM FOTOS. Apresentação de alunas de balé em festividade escolar na Sibéria (1958). 1 fotografia. Disponível em: 〈https://russiainphoto.ru.>. Acesso em: 30 jun. 2017.

A HISTÓRIA DA RÚSSIA EM FOTOS. Aula de física. Professor V. N. Kespikov (1960), Chelyabinsk.1 fotografia. Disponível em: <https://russiainphoto.ru.>. Acesso em: 30 jun. 2017.

A HISTÓRIA DA RÚSSIA EM FOTOS. Aula de ginástica (1973), Moscou. 1 fotografias. Disponível em: <https://russiainphoto.ru.>. Acesso em: 30 jun. 2017.

A HISTÓRIA DA RÚSSIA EM FOTOS. Casa de alojamento, 1921-1922. Chelyabinsk Gubernia. 1 fotografia. Disponível em: <https://russiainphoto.ru.>. Acesso em: 30 jun. 2017.

A HISTÓRIA DA RÚSSIA EM FOTOS. Cidade de Leningrado (hoje São Petersburgo) sitiada pelos nazistas (1942). 1 fotografia. Disponível em: <https://russiainphoto.ru.>. Acesso em: 30 jun. 2017.

A HISTÓRIA DA RÚSSIA EM FOTOS. Corte de cabelo de crianças órfãs em áreas assoladas pela fome, início da década de 1920. 1 fotografia. Disponível em: <https://russiainphoto.ru.>. Acesso em: 30 jun. 2017.

A HISTÓRIA DA RÚSSIA EM FOTOS. Crianças prisioneiras dos nazistas durante a Segunda Guerra Mundial (28/06/1944), Karelo-Finlandês (URSS), Petrozavodsk, campo de concentração n. ${ }^{\circ}$ 6. 1 fotografia. Disponível em: 〈https://russiainphoto.ru.> . Acesso em: 30 jun. 2017.

A HISTÓRIA DA RÚSSIA EM FOTOS. Dia Nacional dos Pioneiros (19. 5. 1968), destacamento na cidade de Yuzhno-Kurilsk (Distrito das Ilhas Curilas do Sul). Nessa data, a juventude soviética realizavaconcertos, desfiles e manifestações que exaltavam os símbolos nacionais. Além disso, coletando sucata, papelão e similares, praticavamas "lições de Lenin" por meio de competições entre unidades escolares (“druzhinami”). 1 fotografia. Disponível em: <https://russiainphoto.ru.>. Acesso em: 30 jun. 2017.

A HISTÓRIA DA RÚSSIA EM FOTOS. Escola de Trabalho "Karl Liebknecht e Rosa Luxemburgo". Transferência dos filhos de camponeses da aldeia de Smolino; mudança da biblioteca, 1923. Chelyabinsk. 1 fotografia. Disponível em: 〈https://russiainphoto.ru.>. Acesso em: 30 jun. 2017 
A HISTÓRIA DA RÚSSIA EM FOTOS. Fazenda estadual "Uysky". Aluno da $6^{\text {a }}$ série A. Butyrnin e o instrutor de trabalho K. V. Vandyshev em atividade nas oficinas escolares durante a década de 1960, região de Chelyabinsk, bairro de Uysk. .1 fotografia. Disponível em: <https://russiainphoto.ru.>. Acesso em: 30 jun. 2017.

A HISTÓRIA DA RÚSSIA EM FOTOS. Jardim de infância; uma caminhada. Uzbek (URSS), década de 1930. 1 fotografia. Disponível em: <https://russiainphoto.ru.>. Acesso em: 30 jun. 2017.

A HISTÓRIA DA RÚSSIA EM FOTOS. Nadezhda Krupskaya num navio a vapor, dezembro de 1929. 1 fotografia. Disponível em: <https://russiainphoto.ru.>. Acesso em: 30 jun. 2017.

A HISTÓRIA DA RÚSSIA EM FOTOS. "Pioneiros" (organização dos adolescentes), em manifestação de rua comemorativa ao Primeiro de maio de 1927, em Moscou. 1 fotografia. Disponível em: <https://russiainphoto.ru.>. Acesso em: 30 jun. 2017.

A HISTÓRIA DA RÚSSIA EM FOTOS. Restaurante escolar (1950-1963). Nas escolas de período integral ou internatos, as crianças, além da educação geral, desenvolviam trabalhos comuns. Nesse internato de Magnitogorsk, à beira do Rio Ural, elas criavam porcos, bezerros, galinhas, coelhos e aprendiam a operar máquinas. 1 fotografia. Disponível em: <https://russiainphoto.ru.>. Acesso em: 30 jun. 2017.

A HISTÓRIA DA RÚSSIA EM FOTOS. Sala de aula (1954). 1 fotografia. Disponível em: <https://russiainphoto.ru.>. Acesso em: 30 jun. 2017.

A HISTÓRIA DA RÚSSIA EM FOTOS. Uma sala de aula, em 1929. 1 fotografia. Disponível em: <https://russiainphoto.ru.>. Acesso em: 30 jun. 2017.

AGANBEGUIAN, A. Uma das lições econômicas da Perestroika. In: POMERANZ, L. (Org.). Perestroica: desafio da transformação social na URSS. São Paulo: Ed. da USP, 1990. p. 49-66.

BITTAR, M.; FERREIRA JUNIOR, A. A educação na Rússia de Lênin. Revista HISTEDBR On-Line, v. 11, p. 377-396, 2012.

BITTAR, M.; FERREIRA JUNIOR, A. Ativismo pedagógico e princípios da escola do trabalho nos primeiros tempos da educação soviética. Revista Brasileira de Educação, v. 20, p. 433-456, 2015.

BOFF, L. A Igreja mente, é cruel, corrupta e sem piedade. Escola \& Humaniversidade, set. 1998. (Entrevista: Frei Beto et al). Disponível em: <http://www.espacoholistico.com. br/artigos-e-praticas/artigos/leonardo-boff-entrevista-com-leonardo-boff.html >. Acesso em: 18 jul. 2017

CABALlERO, M. G. Rusia tras La Perestroika: Propaganda política, cultura y memorias del cambio. Murcia: Ed. da Universidad de Murcia, 2011. 
Artigo

doi: $10.20396 /$ rho.v17i3.8650923

CAMBI, F. História da pedagogia. Tradução: Álvaro Lorencini. São Paulo: Ed. da UNESP, 1999.

FERREIRA JUNIOR, A.; BITTAR, M. A concepção bolchevique da Revolução Socialista. Política Democrática, (Cadernos de Debates), v. 1, p. 08-15, 2007.

FERREIRA JUNIOR, A.; BITTAR, M. Governo de Mikhail Gorbachev (1985-1991), 2017. 1 quadro.

GORBACHEV, M. Perestroika, causa de todos los pueblos del país: discurso en el encuentro con los trabajadores en la ciudad de Kiev. Moscú: Editorial de la Agencia de Prensa Nóvosti, 1989.

GORBACHEV, M. Perestroika: novas ideias para meu país e o mundo. Tradução: J. Alexandre. São Paulo: Best Seller, 1988.

GORBACHEV, M. Pronunciamento à TV estatal da URSS. Folha de S. Paulo, São Paulo, 26 dez. 1991. Caderno Especial, p. 3.

GORBACHEV, M. Reorganização, uma causa vital do povo: discurso proferido no XVIII Congresso dos Sindicatos da URSS a 25 de fevereiro de 1987. Moscovo: Edições da Agência de Imprensa Nóvosti, 1987.

GUDKOV, L.; LEVADA, I.; LEVISON, A.; SEDOV, L. Burocratismo e burocracia: esclarecimentos dos conceitos. In: POMERANZ, L. (Org.). Perestroica: desafios da transformação social na URSS. São Paulo: Ed. da USP, 1990. p. 187-202.

HOBSBAWM, E. Adeus a tudo aquilo. In: BLACKBURN, R. (Org.). Depois da queda: o fracasso do comunismo e o futuro do socialismo. São Paulo: Paz e Terra, 2005. p. 93-106.

HOBSBAWM, E. Era dos extremos: o breve século XX (1914-1991). Tradução: Marcos Santarrita. São Paulo: Companhia das Letras, 1995.

KARPINSKI, L. Por que o stalinismo não sai de cena? In: POMERANZ, L. (Org.). Perestroica: desafios da transformação social na URSS. São Paulo: Ed. da USP, 1990. p. 157-185.

KON, I. A psicologia da inércia social. In: POMERANZ, L. (Org.). Perestroica: desafios da transformação social na URSS. São Paulo: Ed. da USP, 1990. p. 203-218.

LÊNIN, V. I. As tarefas das Uniões da Juventude (Discurso no III Congresso de Toda a Rússia da União Comunista da Juventude da Rússia, 2 de outubro de 1920). In: LÊNIN, V. I. (Org.). Obras escolhidas: em três tomos. São Paulo: Alfa-Omega, 1980a. p. 386-397. t. 3. Instituto de Marxismo-Leninismo do PCUS. 


\section{Revista HIIS'THIDBR On-lime}

ISSN: 1676-2584

Artigo

doi: $10.20396 /$ rho.v17i3.8650923

LÊNIN, V. I. Páginas do diário. In: LÊNIN, V. I. (Org.). Obras escolhidas: em três tomos. São Paulo: Alfa-Omega, 1980b. p. 653-656. t. 3. Instituto de Marxismo-Leninismo do PCUS.

MANACORDA, M. A. Aos educadores brasileiros. Tradução: Paolo Nosella e Patricia Polizel Culhari. Campinas: HISTEDBR/FE UNICAMP, 2007. (Entrevista).

MANACORDA, M. A. História da educação: da Antiguidade aos nossos dias. Tradução: Gaetano Lo Monaco. São Paulo: Cortez; Autores Associados, 1989.

MEDEIROS, C. A. de. A economia política da transição na Rússia. In: PINELI A. A. (Org.). Uma longa transição: vinte anos de transformações na Rússia. Brasília: Instituto de Pesquisa Econômica Aplicada (IPEA), 2011. p. 13-37.

NETTO, J. P. Socialismo Real e a socialização do poder político. Crítica Marxista, n. 1, p. 65-66, 1994.

PANOMARIOV, B. N. História do Partido comunista da União Soviética. Rio de Janeiro: Vitória, 1961.

POMERANZ, L. (Org.). Perestroica: desafios da transformação social na URSS. São Paulo: Ed. da USP, 1990.

SEGRILLO, A. O declínio da União Soviética: um estudo das causas. 2. ed. Curitiba: Prismas, 2013.

TSUKÂNOV, O. A essência e a crise do socialismo feudal de aparelho. In: VICENTE SOBRINHO, P. (Org.). Reflexões sobre a desintegração do comunismo soviético. AlfaOmega, 1995. p. 13-43.

UNIÃO SOVIÉTICA. Gorbachev-Reagan, um passo para a paz: acordos sobre eliminação de mísseis firmados entre URSS e EUA. Rio de Janeiro: Revan, 1988.

UNIÓN SOVIÉTICA. Soviet Supremo de la URSS. Orientaciones fundamentales de la reforma de la enseñanza general y profesional. NM Novedades de Moscú (Suplemento). Moscú, n. 21, (1.139), 1984. p. 03-08.

YAKOVLEV, A. O que queremos fazer da União Soviética: o pai da Perestroika se explica. Rio de Janeiro: Civilização Brasileira, 1991.

YELTSIN, B. A minha luta pela Rússia: o diário de Boris Yeltsin. Rio de Janeiro: Ed. Record, 1994. 
Artigo

doi: $10.20396 /$ rho.v17i3.8650923

Notas

${ }^{1}$ Professora Titular de História, Filosofia e Políticas da Educação da Universidade Federal de São Carlos (UFSCar) e Bolsista de Produtividade em Pesquisa do CNPq.

${ }^{2}$ Professor Titular do Departamento de Educação da Universidade Federal de São Carlos (UFSCar) e Bolsista de Produtividade em Pesquisa do CNPq.

${ }^{3}$ A URSS foi fundada em outubro de 1922. A resolução do Comitê Central do Partido Comunista (bolchevique) da Rússia que aprovou a criação da URSS afirmava o seguinte: "Reconhecer como necessária a conclusão de um acordo entre a Ucrânia, Bielo-Rússia, a Federação das Repúblicas da Transcaucásia e a RSFSR [República Socialista Federativa Soviética da Rússia] acerca de sua unificação na União das Repúblicas Socialistas Soviéticas, mantendo cada uma delas o direito de retirar-se livremente da União". (PANOMARIOV, 1961. p. 345-346).

${ }^{4}$ O Soviete Supremo da URSS era a instância de deliberação máxima do Estado Soviético, com uma composição de aproximadamente 1500 deputados eleitos pelo voto universal e direto sem remuneração financeira para o exercício do cargo, ou seja, eles continuavam a desempenhar plenamente os seus afazeres profissionais concomitantemente às atividades parlamentares. O Soviete Supremo realizava duas plenárias por ano para deliberar (debater, votar e sancionar leis) as diretrizes estatais da URSS. Entre uma sessão e outra, o Soviete Supremo era dirigido permanentemente por um Presidium composto por pouco mais de 40 deputados eleitos entre os pares e com poderes de promulgar decretos governamentais que depois eram submetidos à apreciação do pleno do Soviete Supremo. Contudo, a governança da URSS efetivava-se, na prática, por meio de uma dualidade de poderes na medida em que o Soviete Supremo era um poder estatal homologatório das decisões emanadas do Partido Comunista da União Soviética (PCUS). A Constituição Soviética de 1936 estabelecia, no seu Artigo 126, o seguinte: “(...) os cidadãos mais ativos e conscientes das fileiras da classe operária e de outras camadas dos trabalhadores congregados no Partido Comunista (bolchevique) da URSS, são o destacamento de vanguarda dos trabalhadores em sua luta pela consolidação e desenvolvimento do regime socialista e constituem o núcleo dirigente de todas as organizações dos trabalhadores, tanto social, como estatais" (PANOMARIOV, 1961, p. 476). A última Constituição Soviética (1977), no seu Artigo 6, reafirmou o primado jurídico contido na Carta de 1936 ao estabelecer que "o Partido Comunista da União Soviética é a força líder que lidera e guia a sociedade soviética, constituindo-se no núcleo do seu sistema político e das organizações estatais e socais". (SEGRILLO, 2013, p. 229). Em síntese, o PCUS era a "força líder" que ditava a política estatal promulgada pelo Soviete Supremo da URSS.

${ }^{5}$ Mikhail Sergueyevitch Gorbachev (1931 - ) nasceu em Privolnoye, Território de Stavropol, no sul da Rússia. Estudou Direito na Universidade de Moscou (1955) e Agronomia no Instituto Agrícola de Stavropol (1967). Ingressou no PCUS em 1952 e se tornou membro do Comitê Central em 1971. Em 1980, com apenas 49 anos de idade, foi eleito membro efetivo do Politburo, o órgão máximo de deliberação do PCUS que contava tão somente com 15 membros. Em 1985, após a morte de KonstantinTchernenko (1911-1985), foi eleito secretáriogeral do PCUS.

${ }^{6}$ A XVI Conferência do Partido Comunista (bolchevique) da URSS, realizada em abril de 1929, pôs fim à Nova Política Econômica (NEP), que havia sido introduzida em 1921 após o término da guerra civil (19181920) e que instituiu os Planos Quinquenais. O primeiro Plano Quinquenal (1928-1933) estabeleceu, por exemplo, uma inversão de capital na ordem de 64,6 bilhões de rublos na industrialização de bens de produção (siderurgia, maquinaria, etc.) e na coletivização agrícola, inserindo dois modelos de produção rural: os Sovkhozes (fazendas estatais) e os Kolkhozes (cooperativas). (PANOMARIOV, 1961. p. 407).

${ }^{7}$ O termo socialismo real foi cunhado pela nomenklatura do PCUS, durante a década de 1960, para designar o socialismo realmente existente na URSS, que equivalia também a designá-lo de socialismo desenvolvido ou socialismo maduro. (TSUKÂNOV, 1995, p. 14).

${ }^{8}$ Alexander Yakovlev (1923-2005) foi um dos grandes ideólogos da perestroika e da glasnost. Historiador, cientista político, jornalista e autor de 30 livros. Yakovlev ingressou com apenas 19 anos no Comitê Central do PCUS (1953). Em 1973, recusou-se a restaurar o culto à personalidade de Josef Stalin e foi afastado das decisões do Comitê Central. Por dez anos exerceu as funções de embaixador soviético no Canadá, como parte do seu ostracismo político. Depois, com a ascensão de Gorbachev à Secretária-Geral do PCUS, ele voltou a assumir papel relevante na política partidária e estatal. Como diretor do Departamento de Propaganda do CC do PCUS, nomeou personalidades liberais para dirigir alguns dos principais jornais soviéticos: Izvestia, 
Moskovskiye, Novosti, Ogoniok, Znamia Sovetskaya Cultura. Veterano da Segunda Guerra Mundial (19391945), Yakovlev corrigiu o número de soviéticos mortos no conflito: de 20 milhões para 30 milhões.

${ }^{9}$ Sobre o período histórico correspondente ao governo de Mikhail Gorbachev (1985-1991), as seguintes obras são indispensáveis: GORBACHEV, Mikhail. Perestroika, 1988; POMERANZ, Lenina. Perestroika, 1990; YAKOVLEV, Alexander. O que queremos fazer da União Soviética, 1991; YELTSIN, Boris. A minha luta pela Rússia, 1994; SEGRILLO, Angelo. O declínio da União Soviética, 2013.

${ }^{10}$ No tocante aos estudos que realizamos sobre a Revolução Russa de 1917 e suas consequências imediatas no âmbito da educação, consultar os seguintes artigos: FERREIRA Jr., Amarilio; BITTAR, Marisa. A concepção bolchevique da Revolução Socialista (2007); BITTAR, Marisa; FERREIRA Jr., Amarilio. A educação na Rússia de Lênin (2012); e BITTAR, Marisa; FERREIRA Jr., Amarilio. Ativismo pedagógico e princípios da escola do trabalho nos primeiros tempos da educação soviética (2015).

${ }^{11}$ Entrevista com o educador marxista italiano Mario Alighiero Manacorda, realizada em 2006 por Paolo Nosella na comemoração dos 20 anos do Grupo de Estudos e Pesquisas "História, Sociedade e Educação no Brasil" (HISTEDBR). Em 2007, o HISTEDBR publicou o DVD "Aos educadores brasileiros" - com a entrevista realizada na Itália.

${ }^{12}$ Quanto ao impacto que a corrida armamentista nuclear exerceu sobre a economia da URSS, o historiador brasileiro Angelo Segrillo afirmou o seguinte: "a maioria das estimativas ocidentais apontava que o fardo militar estava atingindo proporções incrivelmente altas na década de 80 , às vésperas da perestroika, e isto numa época em que a economia soviética encontrava dificuldades de crescimento. Vários estudiosos (D. Holloway, W. Lee, M. Castels etc.) citavam o fato de que a defesa poderia estar requisitando recursos que seriam necessários em outras áreas da atividade econômica (principalmente investimento e consumo). Alguns autores chegaram a colocar a questão do fardo militar como uma das questões- chave que levou a economia soviética à beira da estagnação no final da década de 1970 e início da de 1980, sendo, portanto, um dos pontos 'responsáveis' pela necessidade do desencadeamento de uma 'perestroika' do sistema. O caríssimo programa SDI (StrategicDefenseInitiative, conhecido popularmente como 'guerra nas estrelas'), proposto pelo presidente norte-americano Ronald Reagan na década de 1980 teria complicado ainda mais a situação, forçando os soviéticos a manter (ou aumentar) os gastos militares às custas dos já sacrificados outros setores da economia, o que teria sido uma das 'últimas gotas' de estiramento das tensões internas do sistema”. (SEGRILLO, 2013, p. 121).

${ }^{13}$ Para Gorbachev, a perestroika era uma revolução que exerceria impacto sobre as dimensões espirituais e morais da sociedade soviética. Em discurso pronunciado em 1989, ele afirmava: "Tenemos por delante una enorme y tensa labor que está al alcance de nuestras fuerzas. La conclusión principal consiste en que debemos avanzar decididamente por el camino de la reforma económica y política radical; del renacimiento espiritual y moral de la sociedad; no detenerse ante ningún obstáculo, analizar atentamente y de manera crítica el camino recorrido, extraer las lecciones necesarias, hacer en nuestra labor las correcciones que impone la vida, impulsar, con firmeza y paso a paso, la causa de la perestroika. En fin, la perestroika actual, como toda revolución, no es una tarea para débiles e incrédulos. Nuestra propia experiencia constantemente nos lo está demostrando". (GORBACHEV, 1989, p. 7).

${ }^{14}$ Com relação aos elementos ideológicos e subjetivos que perpassavam o sistema burocrático de planejamento da economia soviética, consultar: KON, I. A psicologia da inércia social, 1990; KARPINSKI, Len. Por que o stalinismo não sai de cena?, 1990; GUDKOV, L.; LEVADA, I.; LEVISON, A.; SEDOV,L. Burocratismo e burocracia: esclarecimentos dos conceitos, 1990.

${ }^{15}$ Este texto ditado por Lênin ficou sem título na versão datilografada. Contudo, ele foi publicado, no jornal Pravda (Verdade), em 4 de janeiro de 1923, com o título de "Páginas do Diário" (LÊNIN, 1908b, p. 653).

${ }^{16}$ Nos documentos consta que deveriam ser alfabetizados todos "custe o que custar", o que nos dá a dimensão das resistências que possivelmente ocorriam no campo. A propósito, é interessante notar postura parecida em populações do campo no Brasil, como testemunhou Frei Leonardo Boff ao relatar o caso de sua família imigrante italiana em Santa Catarina. O pai, um erudito em línguas, alfabetizava em italiano. Quando o governo Vargas determinou que a alfabetização fosse feita apenas em português, ele passou a ensinar também em português. Quanto à sua mãe, era analfabeta e não aceitava mudar essa condição. Ele e seu pai pensaram em "mil formas" de convencê-la. A última delas foi uma viagem ao Vaticano de onde trouxeram um caderno e um lápis benzido pelo papa. Ao chegar em casa, lhe disseram o seguinte para convencê-la a aprender: "Isto aqui é bento pelo papa, esta caneta, este caderno". Ao que ela respondeu: "O papa não vale nada, é um bobalhão, eu não quero saber de aprender". (BOFF, Leonardo. A Igreja mente, é cruel, corrupta e sem piedade. 1998. 
Consultado em 18/07/2017: http://www.espacoholistico.com.br/artigos-e-praticas/artigos/leonardo-boffentrevista-com-leonardo-boff.html

17 Para uma compreensão mais detalhada sobre a influência do ativismo pedagógico na educação soviética durante a década de 1920, conferir: BITTAR, Marisa; FERREIRA Jr., Amarilio. A educação na Rússia de Lênin, 2012; BITTAR, Marisa; FERREIRA Jr., Amarilio. Ativismo pedagógico e princípios da escola do trabalho nos primeiros tempos da educação soviética, 2015.

Submetido em: 11/08/2017

Aprovado em: 11/09/2017 